\title{
INTERPRETATION OF HYDROCARBON GENERATION, MIGRATION AND THERMAL HISTORY OF MESOPOTAMIAN BASIN SOUTHERN IRAQ BASED 1D PETROMOD SOFTWARE
}

\author{
${ }^{1}$ Amna M. Handhal, ${ }^{2}$ Muwafaq F. Al-Shahwan and ${ }^{3}$ Hussein A. Chafeet* \\ ${ }^{1,2}$ Department of Geology, Collage of Science, University of Basrah, Basrah, Iraq \\ ${ }^{3}$ Department of Oil and Gas Engineering, College of Oil and Gas Engineering, Basrah University for Oil and \\ Gas, Basrah, Iraq \\ *E-mail: hussein.aliwi@buog.edu.iq
}

Received: 1 August 2019; accepted: 17 October 2019

\begin{abstract}
Seven oilfields are selected in the Mesopotamian basin, southern Iraq for studying thermal history, hydrocarbon generation and migration these are Siba, Zubair, Nahr Umr, Majnoon, Halfaya, Amara and Kumait. The thermal and the basin histories of the basin are modeled using the PetroMod software. Modeling results proved that the generation of oil begins at the end of the Cretaceous and early of Tertiary as a response to the increase of the temperature and burial depth of the Sulaiy and Yamama formations which are in turn accelerate the maturation of organic matter. Therefore, these formations act as main source rocks in the considered basin. The rest of the formations enter the maturation level during Miocene but they aren't capable to generate oil. The migration of oil in both horizontal and vertical directions begins at Miocene in western and southwestern parts of the basin that reflect the significant accumulation of oil in these parts.
\end{abstract}

Keywords: Thermal history; Generation; Migration; Mesopotamian basin

\section{INTRODUCTION}

The oilfields used in this study include Siba, Zubair, Nahr Umr, Majnoon, Halfaya, Kumait, and Amara (Fig. 1). They are located in the southern part of Iraq between $30^{\circ} 58^{\prime}-32^{\circ} 08^{\prime}$ latitude) and (46 $52^{\prime}-47^{\circ} 56^{\prime}$ longitude) within the Mesopotamian basin. The basin is covered by Quaternary fluvial-plain deposits of the Tigris and Euphrates rivers. Beneath this cover, anticlines and horst lie and are mainly related to long lived paleostructures. In the Basrah area in the extreme south of the basin, these structures may also relate to the movement of Infra-Cambrain Hormuz salt (Jassim and Buday, 2006c). The zone was uplifted 
during the Hercynian deformation (Jassim and Goff, 2006). The folds' structures mainly trend NW-SE in the eastern part of the zone and N-S in the southern part, where some structures trending NE-SW occur too (Jassim and Buday, 1987).

The Mesopotamian can be subdivided into three subzones, namely: Euphrates, Tigris, and Zubair. The study area contains oil reservoirs and source rock in Cretaceous and uppermost Jurassic formations at different depths and in a variety of lithologies (Fig. 2). The petroleum system in the basin comprises effective petroleum source rocks represented by Sulaiy and Yamama formations, seal rocks (Tanuma, Shiranish and Rus formations), and reservoir rocks (Yamama, Zubair, Nahr Umr and Mishrif formations) (Amna and Maher, 2016). The evaluation of the source and reservoir characteristics of Albian rock succession, southern Iraq was done by Ibrahim (1983) and concluded that accumulated hydrocarbon in Nahr Umr Formation generated from deepest Cretaceous rocks (Sulaiy and Yamama). AlMousawi (1996) used palynofacies to determine the hydrocarbon generation potential of the Sulaiy Formation and assessed that the Sulaiy Formation is an efficient source rock in southern Iraq. Al-Ahmed (2006) showed that the Sargelu Formation are source rocks in the north of Iraq that charge Cretaceous and Tertiary reservoir oil. The oil is of two families, family one is from Sargelu formation while family two is from Sargelu and lower Cretaceous source rocks. Al-Khafaji (2006) used biomarkers and carbon isotopes in the correlation between Mishrif crude oil and possible source rocks in Southern Iraq. He concluded that most of the crude oil accumulated in the Mishrif Formation in Ratawi, north and south Rumaila oil fields are from Jurassic source rocks such as Najmah and Sargelu formations, but the rest of the oil is from Sulaiy Formation. Al-Yaseri (2007) evaluated the thermal maturation, hydrocarbon generation potential and identification of Tar-mat deposits for the uppermost Jurassic (Gotnia Formation) and Cretaceous (Sulaiy, Yamama, Ratawi, Shuaiba, Nahr Umr and Mishrif formations) at southern Iraq. His results indicated that the lower Cretaceous formations contain a sufficient amount of oil-prone (Type II\&III) predominately marine organic matter. Results of biomarkers of crude oil indicated that they are generated from carbonate source rocks include algal and bacteria organic matter deposited in an anoxic environment. Al-Haidari (2009) studied the biomarkers of Zubair Formation oil and its sources in the Basra region, southern Iraq. Based on her study, the source rock of oil is carbonate (Sulaiy-Yamama formations) that deposited in the reduced marine environment and mature kerogen type II with algae. This study aims to evaluate the thermal maturity of the different formations in the basin, determine the timing of hydrocarbon generation and 
expulsion, construct the geological history of the basin, calculate the heat flow and overburden pressure to reconstruct the 1D basin modeling.

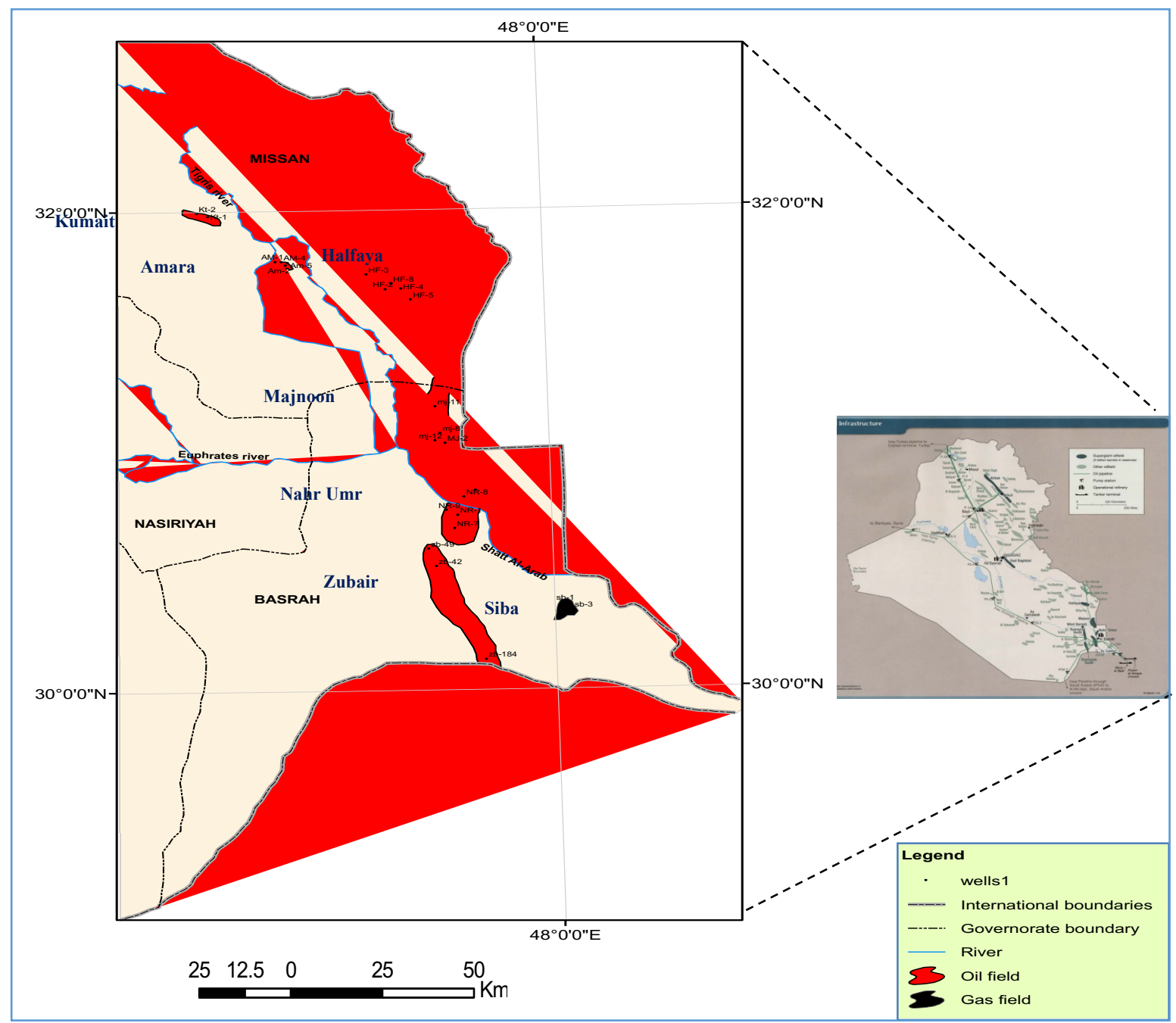

Fig. 1: Map of the studied fields and wells 


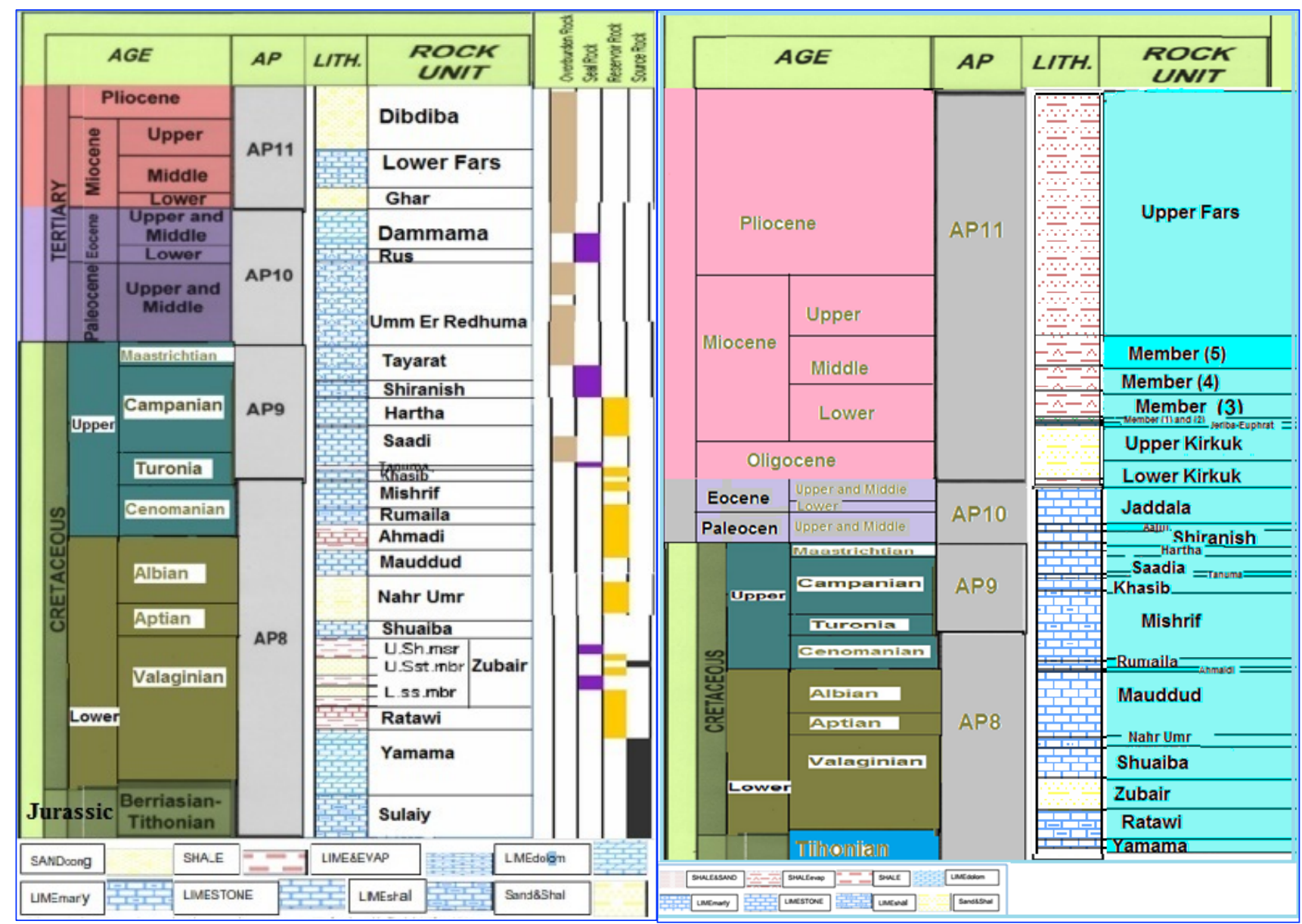

Fig. 2: Stratigraphic columns in southern Iraq (Sadooni and Aqrawi, 2000) (A)Zubair oilfield (Zb-42) and (B) Halfaya oilfield (HF-4)

\section{METHODS}

The burial history and thermal maturity of the basin were constructed using 1D PetroMod. The main input data includes age and thickness. TOC and HI, kinetic data are also used to construct the thermal history, generation and migration models, (Fig. 3). Data for boundary conditions such as heat flow also used. Heat flow is computed as (MaCulloh and Naeser, 1989):

$Q_{z}=k \frac{d t}{d z}$

Where:

$Q_{z}$ : Vertical component of heat flow $\left(\mathrm{MW} \cdot \mathrm{m}^{-1}\right) ; k$ : thermal conductivity $\left(\mathrm{W} \cdot \mathrm{m}^{-1} \cdot{ }^{\circ} \mathrm{C}^{-1}\right)$.

$\frac{d t}{d z}$ : Geothermal gradient $\left({ }^{\circ} \mathrm{C} / \mathrm{km}\right)$. 


\begin{tabular}{|c|c|c|c|c|c|c|c|c|c|c|c|c|c|c|}
\hline \multicolumn{15}{|c|}{ 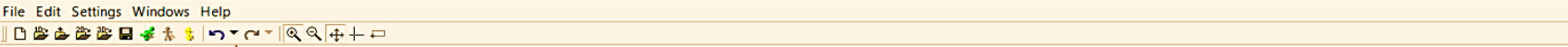 } \\
\hline \multirow{2}{*}{ 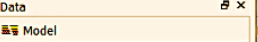 } & \multirow{2}{*}{\multicolumn{14}{|c|}{$\begin{array}{l}\text { Moin Input for } 2 b-42 \\
\text { Depth Input: }{ }^{\circ} \text { Top } r \text { Base } r \text { Thickness Assign from Well Pick }\end{array}$}} \\
\hline & & & & & & & & & & & & & & \\
\hline \multirow[t]{10}{*}{ 箇 $2 \mathrm{~b}-42$} & \\
\hline & Layer & $\begin{array}{l}\text { Top } \\
\text { [m] }\end{array}$ & $\begin{array}{l}\text { Base } \\
{[\mathrm{m}]}\end{array}$ & $\begin{array}{c}\text { Thick. } \\
{[\mathrm{m}]}\end{array}$ & $\begin{array}{c}\text { Eroded } \\
{[\mathrm{m}]}\end{array}$ & $\begin{array}{l}\text { Depo. } \\
\text { from } \\
\text { [Ma] }\end{array}$ & $\begin{array}{c}\text { Depo. } \\
\text { to } \\
\text { [Ma] }\end{array}$ & $\begin{array}{c}\text { Eroded } \\
\text { from } \\
\text { [Ma] }\end{array}$ & $\begin{array}{c}\text { Eroded } \\
\text { to } \\
\text { [Ma] }\end{array}$ & Lithology & PSE & $\begin{array}{l}\text { TOC } \\
{[\%]}\end{array}$ & Kinetic & $\begin{array}{c}\mathrm{HI} \\
\mathrm{mgHC} / \mathrm{gTOC}\end{array}$ \\
\hline & Dibdiba & 0 & 364 & 364 & 350 & 10.20 & 5.00 & 5.00 & 0.00 & SANDcongI & & & & \\
\hline & Lower Fares & 364 & 573 & 209 & & 16.50 & 10.20 & & & LIMEmarly & & & & \\
\hline & Ghar & 573 & 697 & 124 & & 23.00 & 16.50 & & & SANDcongl & & & & \\
\hline & Dammam & 697 & 920 & 223 & 491 & 45.00 & 36.50 & 36.50 & 23.00 & LIMEdolom & & & & \\
\hline & Rus & 920 & 990 & 70 & & 53.00 & 45.00 & & & LIME\&EVAP & & & & \\
\hline & Umm Er Rachuma & 990 & 1454 & 464 & & 62.30 & 53.00 & & & LIME\&EVAP & & & & \\
\hline & Tayarat & 1454 & 1658 & 204 & 282 & 68.20 & 65.00 & 65.00 & 62.30 & LIME\&EVAP & & & & \\
\hline & Shiranish & 1658 & 1749 & 91 & & 70.40 & 68.20 & & & LIMEmarly & & & & \\
\hline \multirow{13}{*}{ 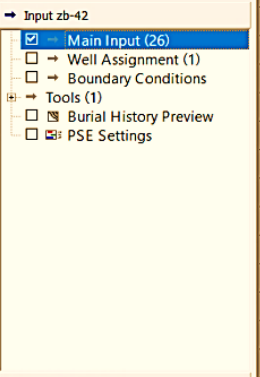 } & Hartha & 1749 & 1907 & 158 & & 80.00 & 70.40 & & & LIMESTONE & & & & \\
\hline & Sadi & 1907 & 2125 & 218 & & 86.00 & 80.00 & & & LIMESTONE & & & & \\
\hline & Tanuma & 2125 & 2150 & 25 & & 87.00 & 86.00 & & & SHALE & Seal Rock & & & \\
\hline & Khasib & 2150 & 2213 & 63 & & 89.00 & 87.00 & & & LIMESTONE & Reservoir Rock & & & \\
\hline & Mishrif & 2213 & 2364 & 151 & 100 & 92.00 & 90.00 & 90.00 & 89.00 & LIMESTONE & Reservoir Rock & & & \\
\hline & Rumaila & 2364 & 2455 & 91 & & 93.00 & 92.00 & & & LIMEshaly & & & & \\
\hline & Ahmadi & 2455 & 2601 & 146 & & 94.00 & 93.00 & & & SHALE\&LIME & & & & \\
\hline & Mauddud & 2601 & 2740 & 139 & & 95.00 & 94.00 & & & LIMESTONE & & 0.40 & Abu-Ali(1999)_III-(Qusaiba) & 555.02 \\
\hline & Naher Umr & 2740 & 2998 & 258 & & 107.00 & 95.00 & & & SAND\&SHALE & Reservoir Rock & 0.78 & Abu-Ali(1999)_TII-(Qusaiba) & 20.00 \\
\hline & Shuaiba & 2998 & 3096 & 98 & & 112.00 & 107.00 & & & LIMESTONE & & 0.76 & Abu-Ali(1999)_III-(Qusaiba) & \\
\hline & U.Sh.msr & 3096 & 3197 & 100 & & 113.00 & 112.00 & & & SHALE & Seal Rock & 0.82 & Abu-Ali(1999)_III-(Qusaiba) & \\
\hline & U.Sst.mbr & 3197 & 3300 & 102 & & 114.00 & 113.00 & & & SANDSTONE & Reservoir Rock & 0.67 & Abu-Ali(1999)_III-(Qusaiba) & \\
\hline & M.Sh.mbr & 3300 & 3361 & 62 & & 115.00 & 114.00 & & & SHALE & Source Rock & 0.89 & Abu-Ali(1999)_TII-(Qusaiba) & \\
\hline \multirow{2}{*}{$\begin{array}{l}+ \text { Simulation } 2 \mathrm{~b}-42 \\
+ \text { Output } 2 \mathrm{~b}-42\end{array}$} & L.ss.mbr & 3361 & 3423 & 62 & & 116.00 & 115.00 & & & SANDSTONE & Reservoir Rock & & Abu-Ali(1999)_TII-(Qusaiba) & \\
\hline & L.Sh.mbr & 3423 & 3473 & 50 & & 118.00 & 116.00 & & & SHALE & Seal Rock & 0.72 & Abu-Ali(1999)_TII-(Qusaiba) & \\
\hline \multirow[t]{4}{*}{ Info } & Ratawi & 3473 & 3605 & 132 & & 125.00 & 118.00 & & & SHALE\&LIME & Source Rock & 0.68 & Abu-Ali(1999)_III-(Qusaiba) & 545.82 \\
\hline & Yamama & 3605 & 3972 & 367 & & 135.00 & 125.00 & & & LIMEdolom & Reservoir Rock & 1.16 & Abu-Ali(1999)_TII-(Qusaiba) & 632.34 \\
\hline & Sulaiy & 3972 & 4209 & 237 & & 140.00 & 135.00 & & & LIMEshaly & Source Rock & 1.07 & Abu-Ali(1999)_TII-(Qusaiba) & 644.08 \\
\hline & & & & & & & tanan & & & & & & & \\
\hline
\end{tabular}

Fig. 3: The main input data to the PetroMod software

The thermal conductivity was calculated as Selley (1998)

$$
k=k_{m}^{(1-\phi)} * k_{w}^{\phi}
$$

Where:

$k$ : bulk thermal conductivity.

$k_{w}$ : water conductivity $\left(0.59 \mathrm{~W} \cdot \mathrm{m}^{-1} \cdot{ }^{\circ} \mathrm{C}^{-1}\right)$.

$\phi$ : porosity (\%) (Calculate from well logs).

$\mathrm{k}_{\mathrm{m}}$ : rock matrix conductivity (1.45 for Shale, 3.75 for Dolomite, 2.64 for Sandstone, 2.56 for Limestone, 5.4 for Anhydrite).

The steps for calculating heat flow are:

1. The porosity was calculated via density, neutron, and sonic logs.

2. Lithological sections of wells were used to assign the $\mathrm{km}$ values.

3. The value of Ts, TD and BHT from well logs records were used for estimating for the geothermal gradient.

Applying the above equations show reasonable values of heat flows. These values range 27 to $70 \mathrm{MW} / \mathrm{m}^{2}$ that may reflect the maturity of the organic matter (Fig. 4). The paleowater depths 
for the studied wells were estimated depending upon the depositional environments for each formation.

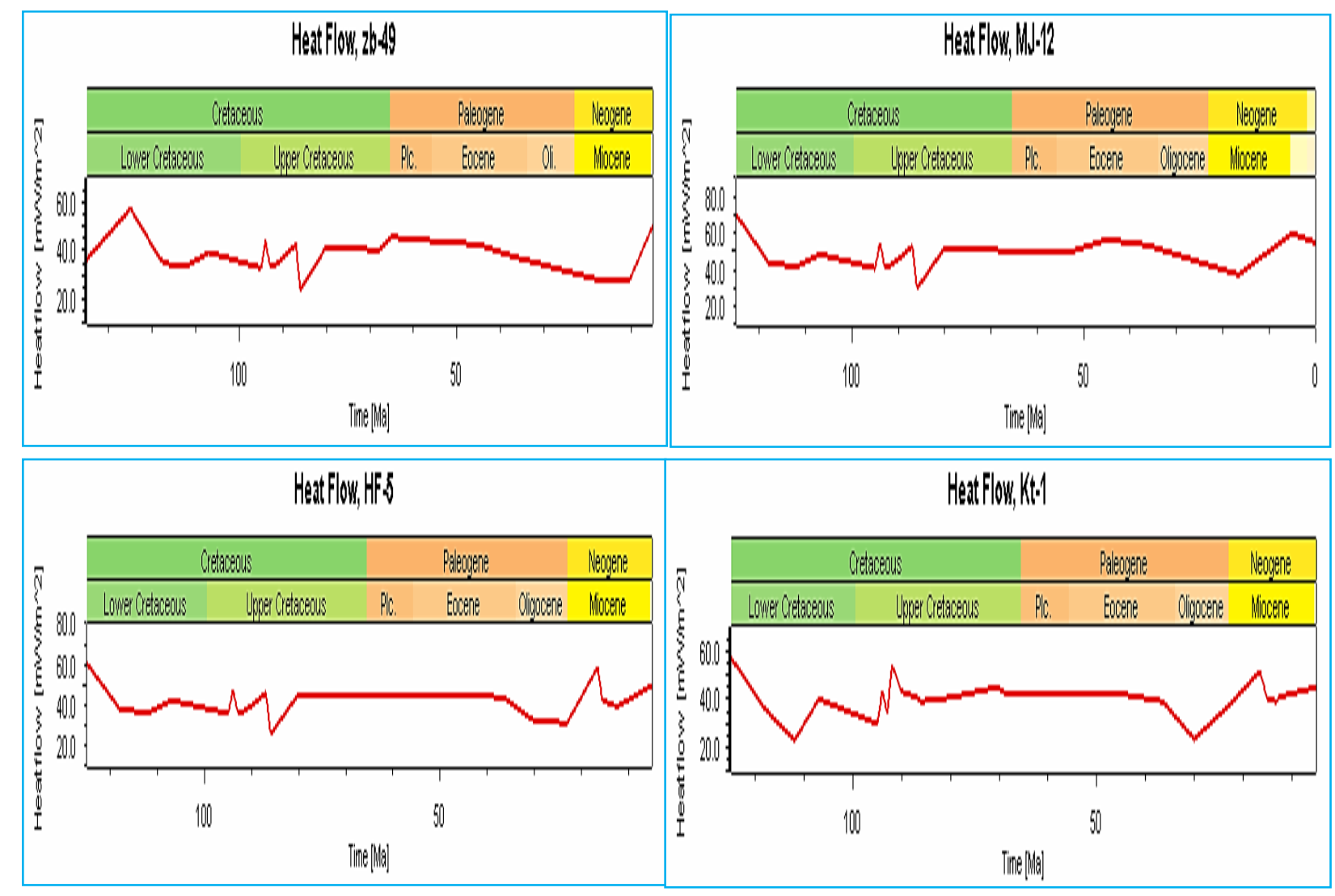

Fig. 4: Heat flow of the selected wells in the study area

\section{RESULTS AND DISCUSSION}

\section{Petroleum Generation}

\section{A. Vitrinite Reflectance (Ro)}

Vitrinite reflectance is an optical parameter that widely used as an indicator to describe the organic matter maturity (Allen and Allen, 2005). For values (Ro) are not constant for each formation, but shows the time of entry into the maturity stage of each formation according to the algorithm developed by Sweeney and Burnham (1990), and value (0.55) represents the beginning of maturity as shown in Figures (5 to 12) and (Table. 1). 

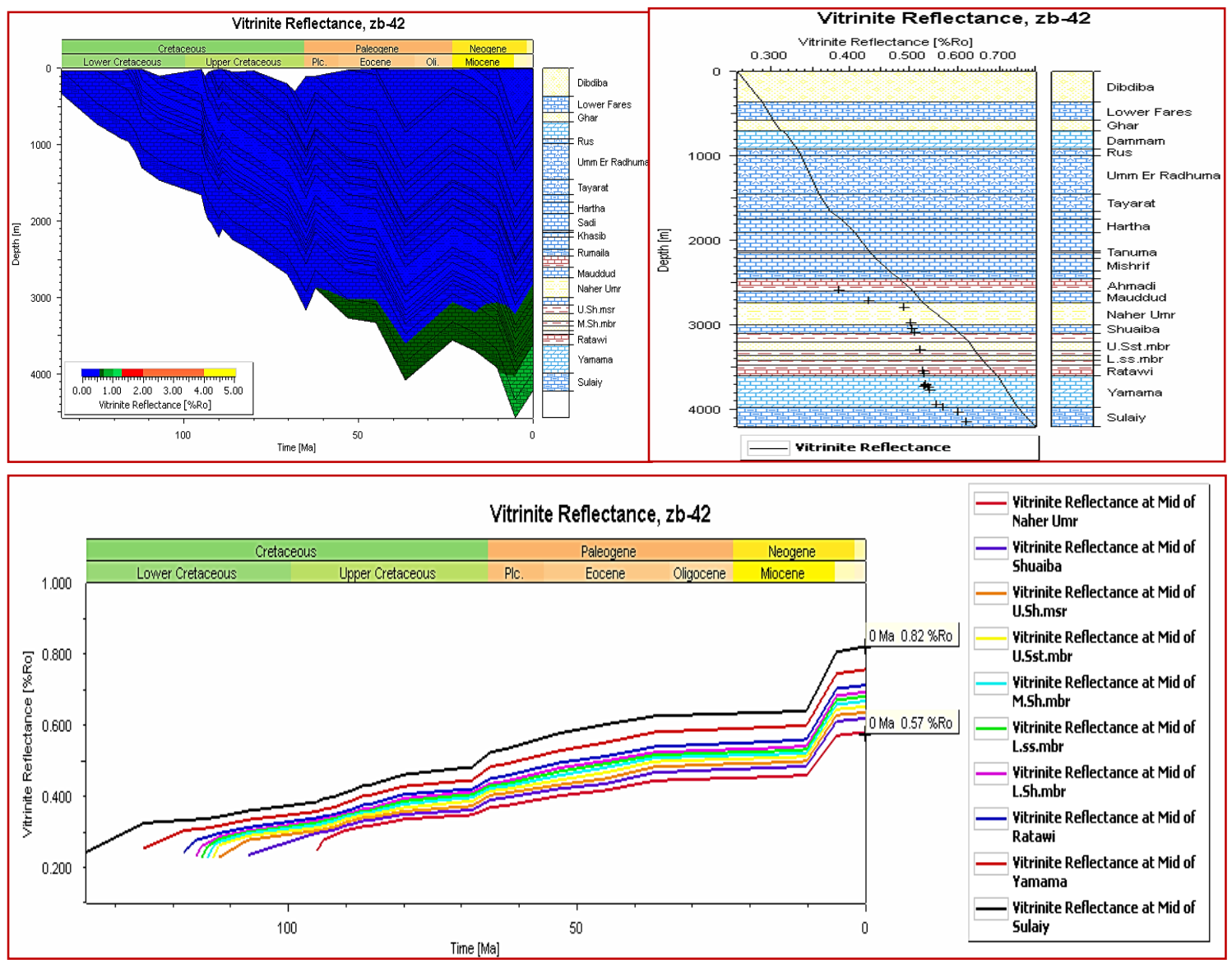

Fig. 5: Vitrinite reflectance for well $\mathrm{Zb}-42$
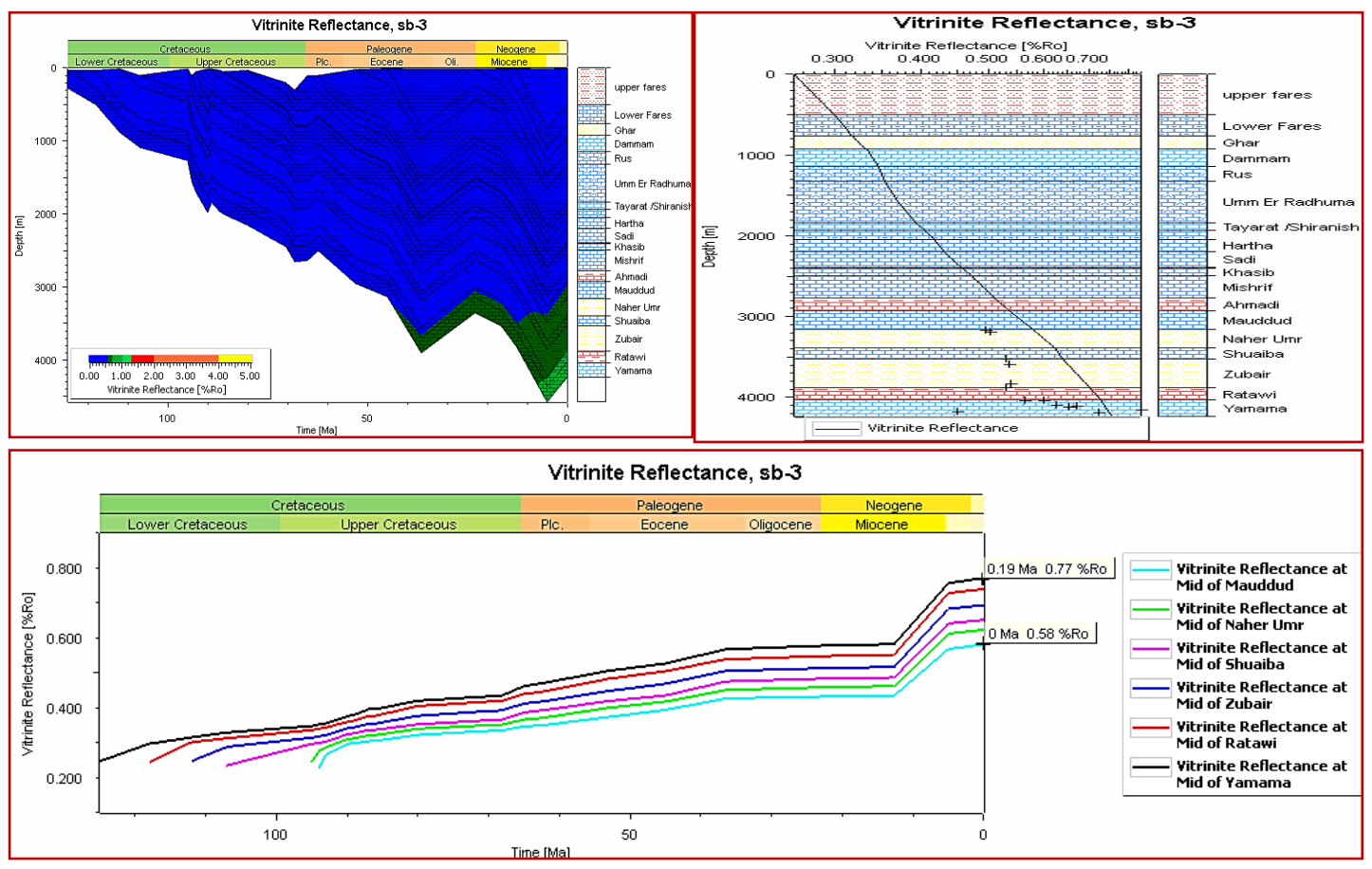

Fig. 6: Vitrinite reflectance for well Sb-3 

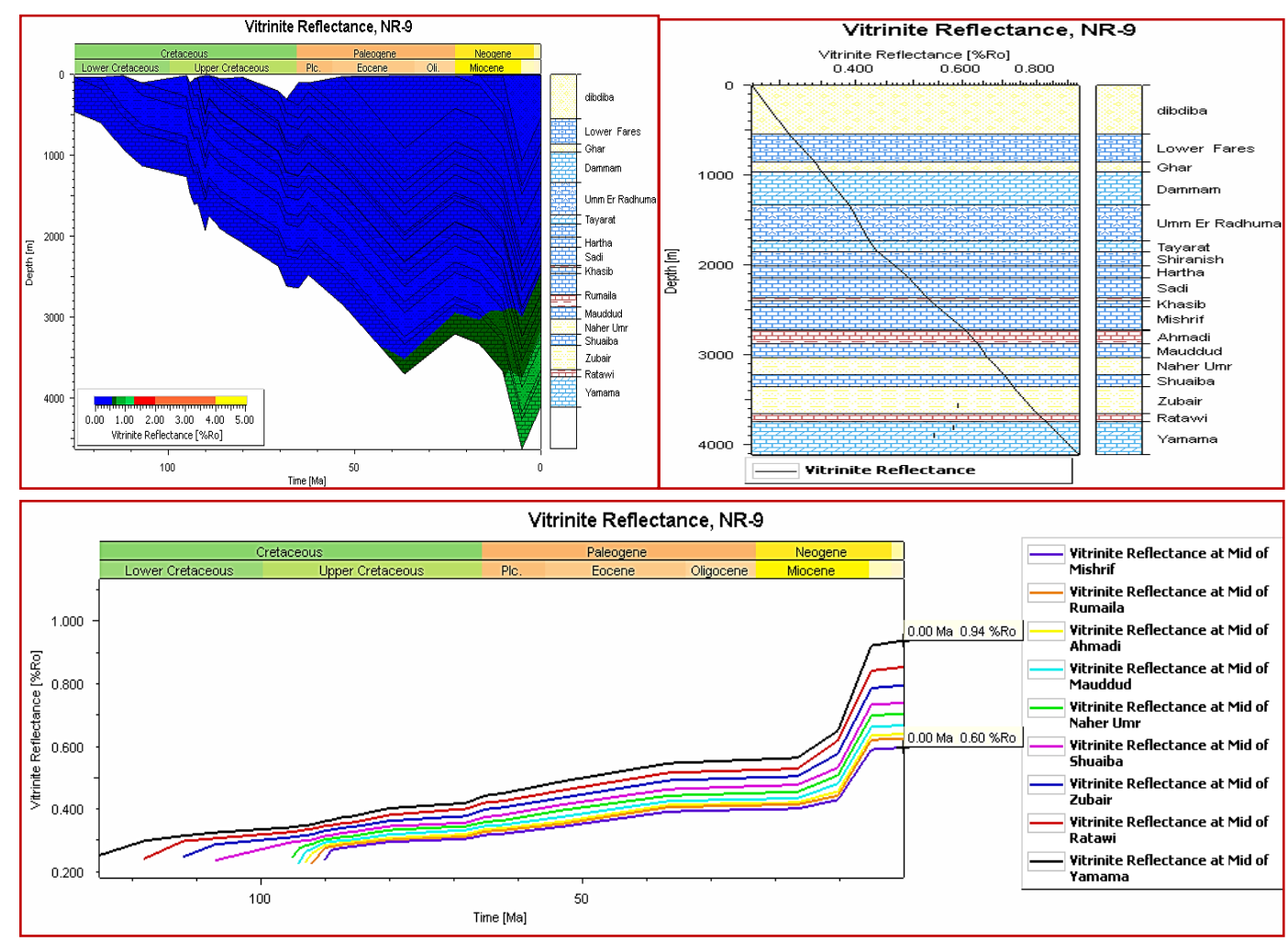

Fig. 7: Vitrinite reflectance for well NR-9
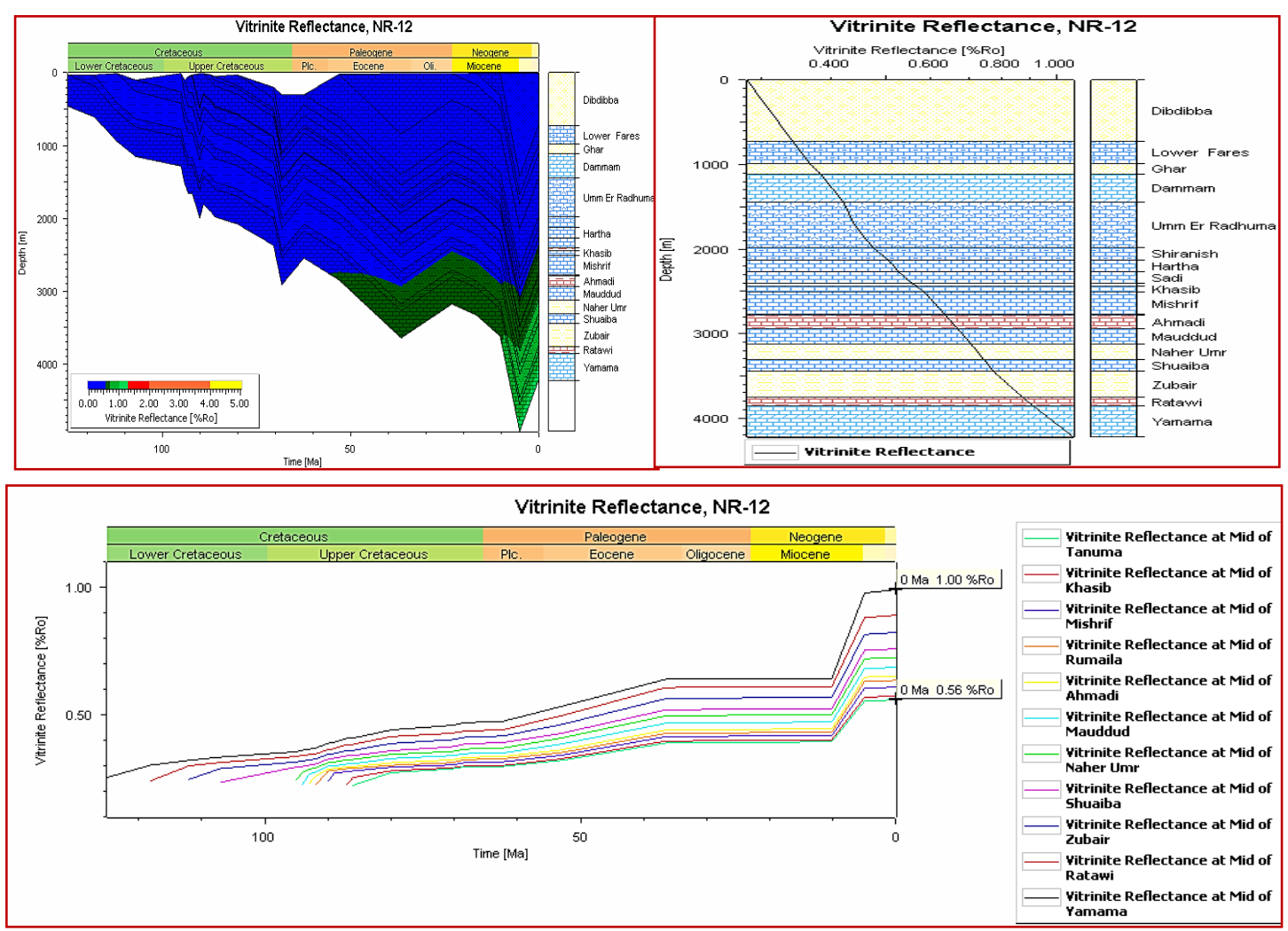

Fig. 8: Vitrinite reflectance for well NR-12 

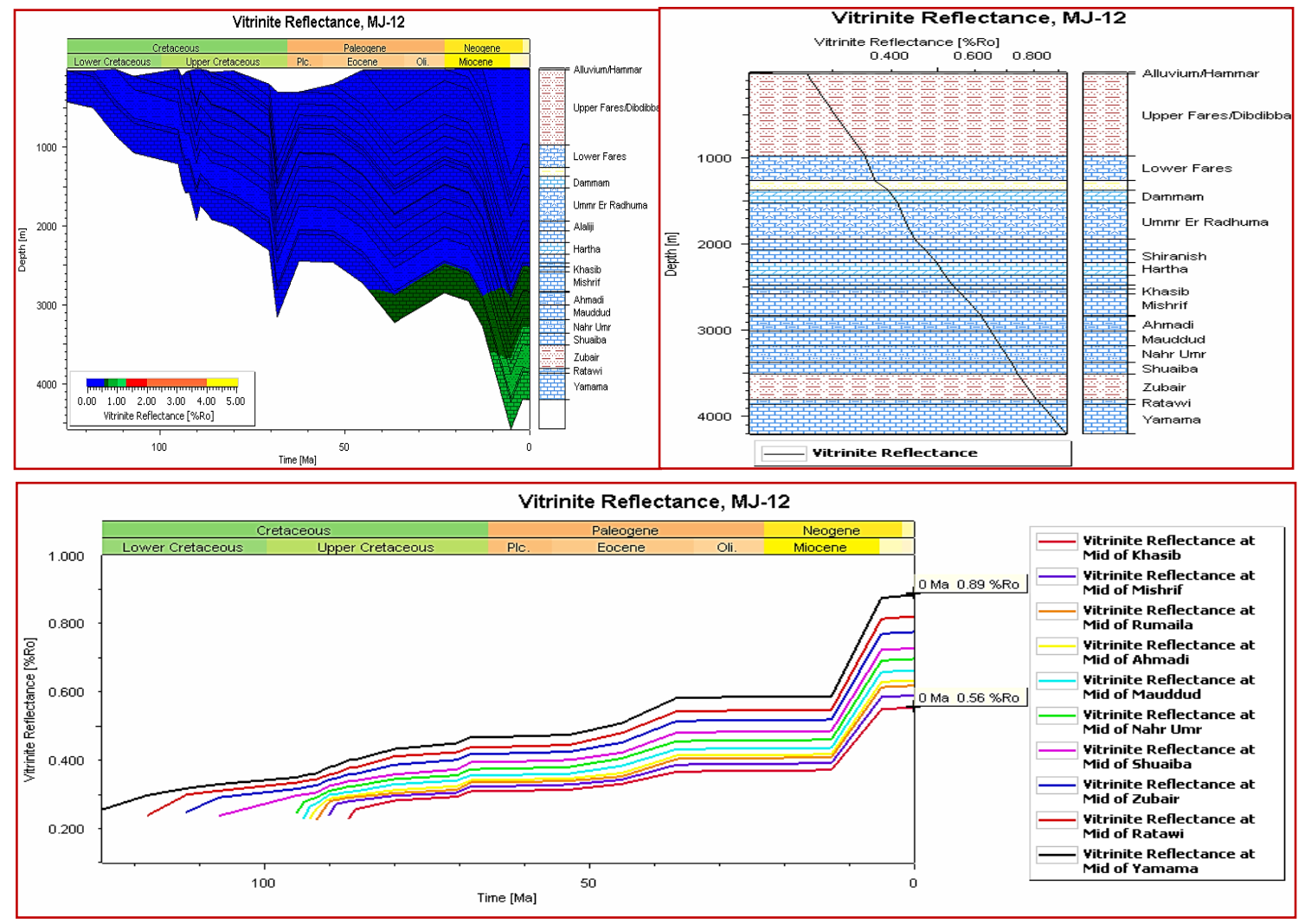

Fig. 9: Vitrinite reflectance for well $\mathrm{Mj}-12$
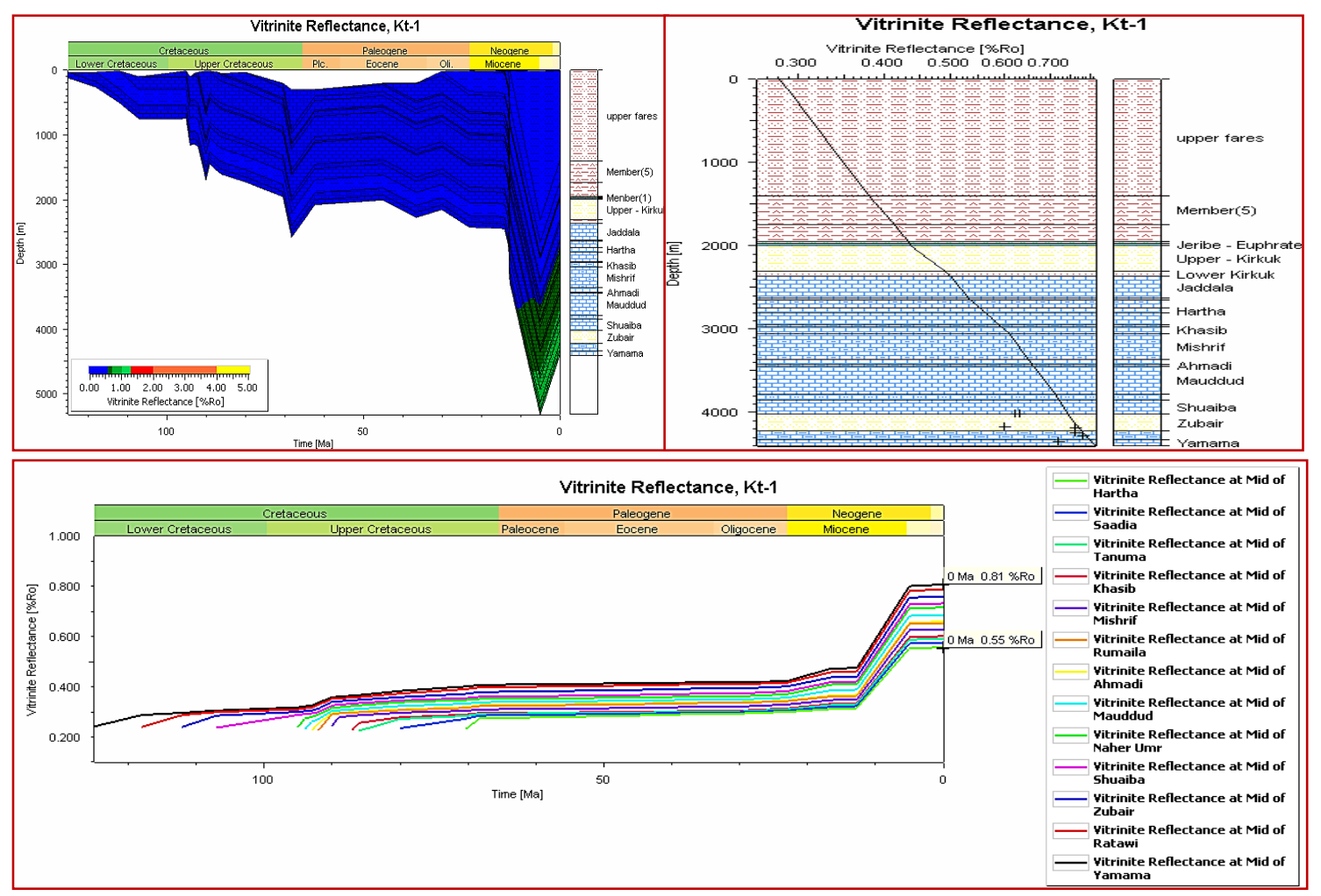

Fig. 10: Vitrinite reflectance for well Kt-1 

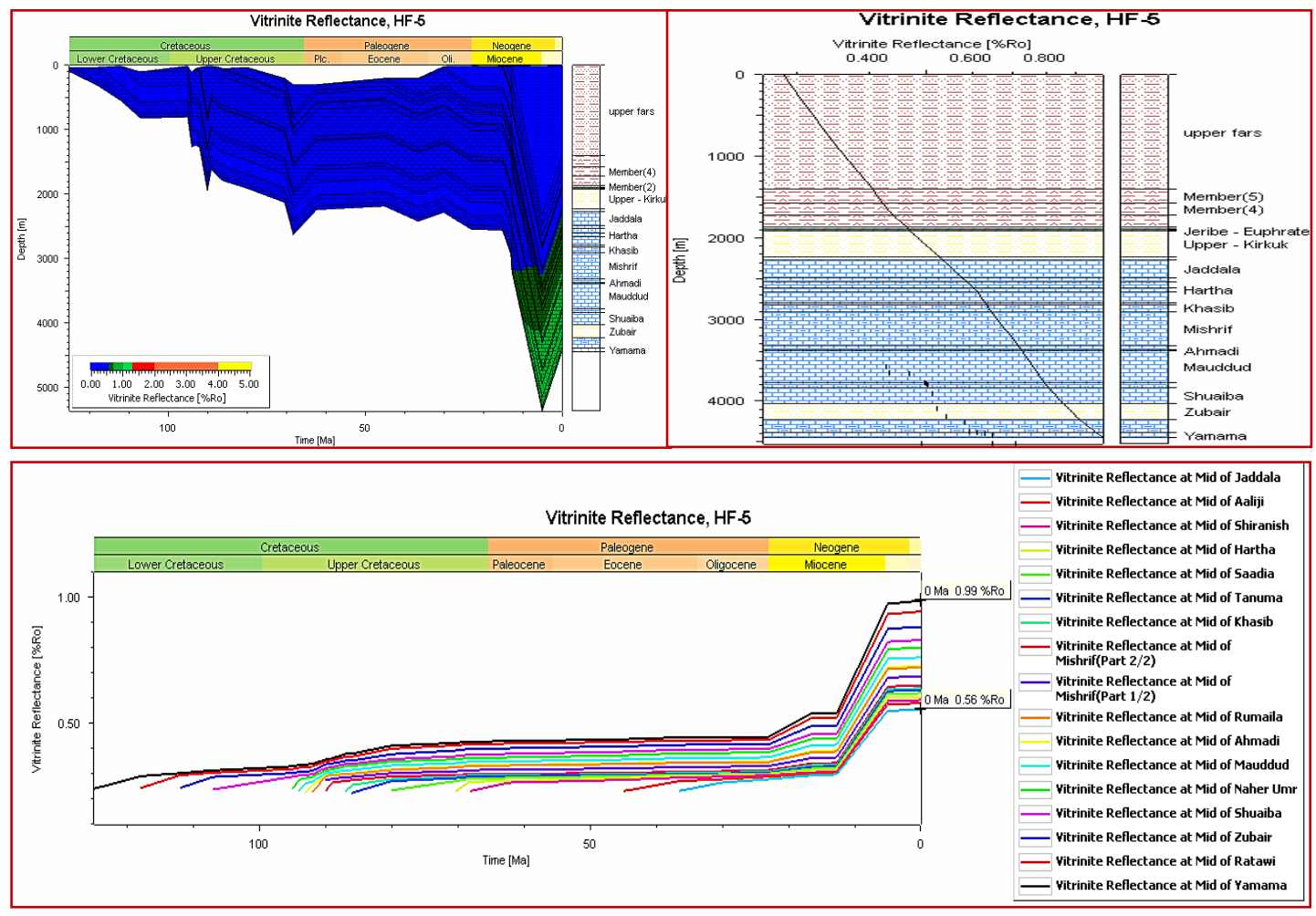

Fig. 11: Vitrinite reflectance for well HF-5

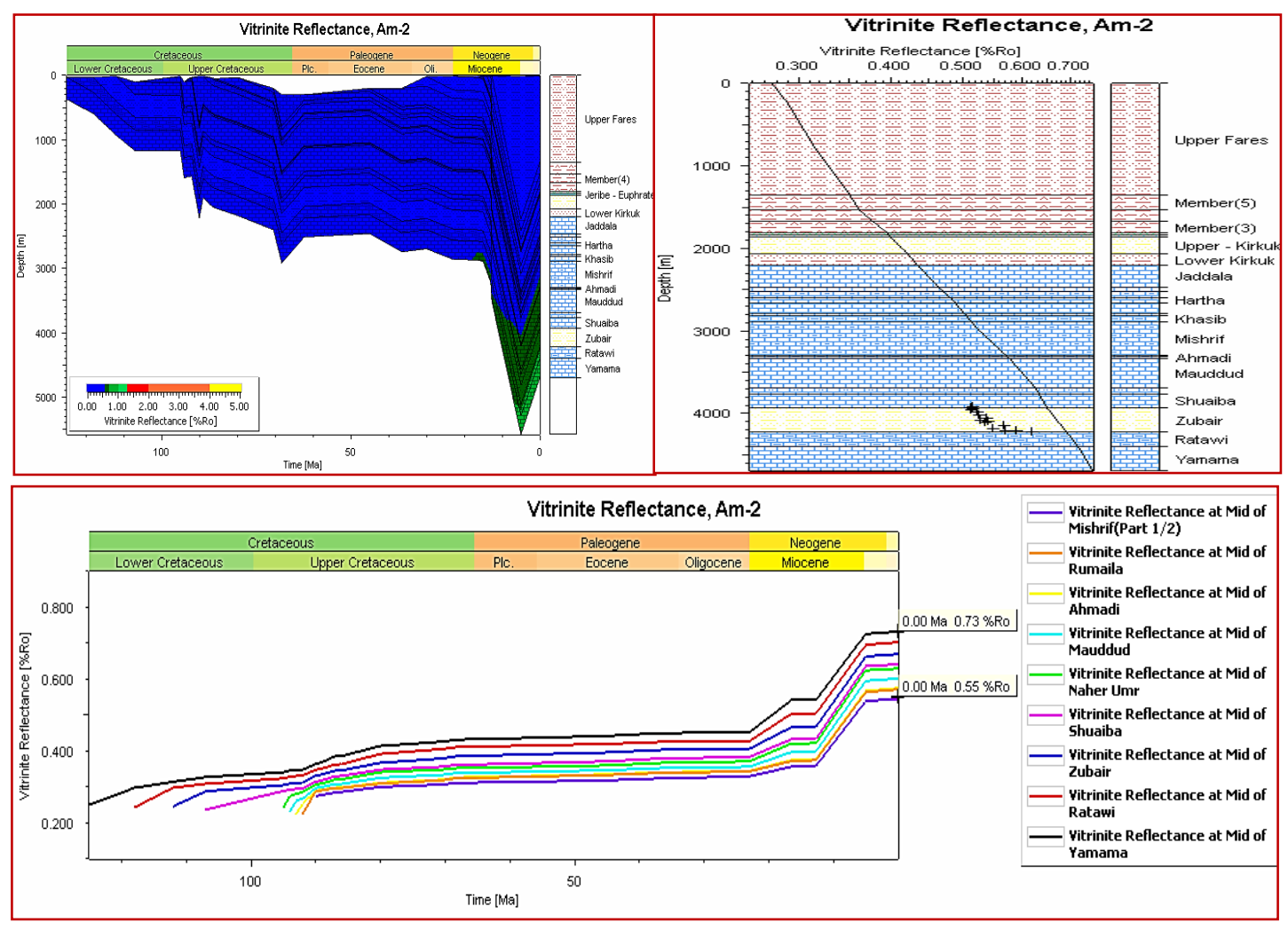

Fig. 12: Vitrinite reflectance for well Am-2 
Table 1: Vitrinite reflectance values for the studied wells

\begin{tabular}{|c|c|c|c|c|c|c|c|}
\hline \multirow[b]{2}{*}{ Well No. } & \multirow[b]{2}{*}{ Fn. } & \multicolumn{2}{|c|}{ Start } & \multirow[b]{2}{*}{ Stage } & \multicolumn{2}{|c|}{ End } & \multirow[b]{2}{*}{ Stage } \\
\hline & & Ro \% & $\begin{array}{l}\text { Time } \\
\text { (Ma) }\end{array}$ & & Ro\% & $\begin{array}{l}\text { Time } \\
\text { (Ma) }\end{array}$ & \\
\hline \multirow{8}{*}{$\mathrm{Zb}-42$} & Sulaiy & 0.55 & 58.05 & Early oil & 0.82 & 0 & Main oil \\
\hline & Yamama & 0.55 & 38.96 & Early oil & 0.72 & 0 & Main oil \\
\hline & Ratawi & 0.55 & 14.16 & Early oil & 0.68 & 0 & Early oil \\
\hline & L. Sst. Member & 0.55 & 10.54 & Early oil & 0.65 & 0 & Early oil \\
\hline & M. Sh. Member & 0.55 & 9.88 & Early oil & 0.64 & 0 & Early oil \\
\hline & U. Sst. Member & 0.55 & 9.04 & Early oil & 0.63 & 0 & Early oil \\
\hline & Shuaiba & 0.55 & 7.13 & Early oil & 0.59 & 0 & Early oil \\
\hline & Nahr Umr & 0.55 & 4.43 & Early oil & 0.56 & 0 & Early oil \\
\hline \multirow[t]{4}{*}{ Sb-3 } & Yamama & 0.55 & 41.04 & Early oil & 0.77 & 0 & Main oil \\
\hline & Ratawi & 0.55 & 26.38 & Early oil & 0.72 & 0 & Main oil \\
\hline & Zubair & 0.55 & 11.01 & Early oil & 0.67 & 0 & Early oil \\
\hline & Shuaiba & 0.55 & 9.27 & Early oil & 0.63 & 0 & Early oil \\
\hline \multirow[t]{2}{*}{ Sb-3 } & Nahr Umr & 0.55 & 7.6 & Early oil & 0.6 & 0 & Early oil \\
\hline & Mauddud & 0.55 & 4.39 & Early oil & 0.58 & 0 & Early oil \\
\hline \multirow[t]{9}{*}{ NR-9 } & Yamama & 0.55 & 37.29 & Early oil & 0.94 & 0 & Main oil \\
\hline & Ratawi & 0.55 & 14.95 & Early oil & 0.82 & 0 & Main oil \\
\hline & Zubair & 0.55 & 12.69 & Early oil & 0.77 & 0 & Main oil \\
\hline & Shuaiba & 0.55 & 9.63 & Early oil & 0.71 & 0 & Main oil \\
\hline & Nahr Umr & 0.55 & 8.87 & Early oil & 0.68 & 0 & Early oil \\
\hline & Mauddud & 0.55 & 8.15 & Early oil & 0.65 & 0 & Early oil \\
\hline & Ahmadi & 0.55 & 7.44 & Early oil & 0.63 & 0 & Early oil \\
\hline & Rumaila & 0.55 & 6.59 & Early oil & 0.61 & 0 & Early oil \\
\hline & Mishrif & 0.55 & 5.58 & Early oil & 0.6 & 0 & Early oil \\
\hline \multirow[t]{11}{*}{ NR-12 } & Yamama & 0.55 & 51.67 & Early oil & 1 & 0 & Late oil \\
\hline & Ratawi & 0.55 & 46.81 & Early oil & 0.89 & 0 & Main oil \\
\hline & Zubair & 0.55 & 40.51 & Early oil & 0.83 & 0 & Main oil \\
\hline & Shuaiba & 0.55 & 9.45 & Early oil & 0.76 & 0 & Main oil \\
\hline & Nahr Umr & 0.55 & 9.18 & Early oil & 0.73 & 0 & Main oil \\
\hline & Mauddud & 0.55 & 8.15 & Early oil & 0.69 & 0 & Early oil \\
\hline & Ahmadi & 0.55 & 7.59 & Early oil & 0.65 & 0 & Early oil \\
\hline & Rumaila & 0.55 & 7.05 & Early oil & 0.64 & 0 & Early oil \\
\hline & Mishrif & 0.55 & 6.6 & Early oil & 0.61 & 0 & Early oil \\
\hline & Khasib & 0.55 & 5.51 & Early oil & 0.58 & 0 & Early oil \\
\hline & Tanuma & 0.55 & 5.3 & Early oil & 0.56 & 0 & Early oil \\
\hline \multirow[t]{8}{*}{$\mathrm{Mj}-12$} & Yamama & 0.55 & 41.04 & Early oil & 0.89 & 0 & Main oil \\
\hline & Ratawi & 0.55 & 36.58 & Early oil & 0.82 & 0 & Main oil \\
\hline & Zubair & 0.55 & 11.76 & Early oil & 0.78 & 0 & Main oil \\
\hline & Shuaiba & 0.55 & 10.88 & Early oil & 0.73 & 0 & Main oil \\
\hline & Nahr Umr & 0.55 & 9.98 & Early oil & 0.7 & 0 & Main oil \\
\hline & Mauddud & 0.55 & 9.09 & Early oil & 0.66 & 0 & Early oil \\
\hline & Ahmadi & 0.55 & 8.06 & Early oil & 0.63 & 0 & Early oil \\
\hline & Rumaila & 0.55 & 7.05 & Early oil & 0.62 & 0 & Early oil \\
\hline \multirow[t]{6}{*}{ Kt-1 } & Yamama & 0.55 & 11.04 & Early oil & 0.81 & 0 & Main oil \\
\hline & Ratawi & 0.55 & 10.62 & Early oil & 0.79 & 0 & Main oil \\
\hline & Zubair & 0.55 & 9.89 & Early oil & 0.76 & 0 & Main oil \\
\hline & Shuaiba & 0.55 & 9.45 & Early oil & 0.73 & 0 & Main oil \\
\hline & Nahr Umr & 0.55 & 9.18 & Early oil & 0.71 & 0 & Main oil \\
\hline & Mauddud & 0.55 & 8.62 & Early oil & 0.69 & 0 & Early oil \\
\hline
\end{tabular}


Table 1: continued....

\begin{tabular}{|c|c|c|c|c|c|c|c|}
\hline Kt-1 & Ahmadi & 0.55 & 7.7 & Early oil & 0.66 & 0 & Early oil \\
\hline & Rumaila & 0.55 & 7.67 & Early oil & 0.66 & 0 & Early oil \\
\hline & Mishrif & 0.55 & 7.2 & Early oil & 0.63 & 0 & Early oil \\
\hline & Khasib & 0.55 & 6.67 & Early oil & 0.6 & 0 & Early oil \\
\hline & Tanuma & 0.55 & 6.02 & Early oil & 0.59 & 0 & Early oil \\
\hline & Sadi & 0.55 & 5.07 & Early oil & 0.58 & 0 & Early oil \\
\hline & Hartha & 0.55 & 5.16 & Early oil & 0.55 & 0 & Early oil \\
\hline \multirow[t]{14}{*}{ HF-5 } & Yamama & 0.55 & 15.83 & Early oil & 0.99 & 0 & Main oil \\
\hline & Ratawi & 0.55 & 12.39 & Early oil & 0.94 & 0 & Main oil \\
\hline & Zubair & 0.55 & 11.76 & Early oil & 0.89 & 0 & Main oil \\
\hline & Shuaiba & 0.55 & 11.06 & Early oil & 0.83 & 0 & Main oil \\
\hline & Nahr Umr & 0.55 & 10.61 & Early oil & 0.81 & 0 & Main oil \\
\hline & Mishrif (1/2) & 0.55 & 6 & Early oil & 0.62 & 0 & Early oil \\
\hline & Mishrif (2/2) & 0.55 & 5.1 & Early oil & 0.58 & 0 & Early oil \\
\hline & Khasib & 0.55 & 3.34 & Early oil & 0.57 & 0 & Early oil \\
\hline & Tanuma & 0.55 & 1.58 & Early oil & 0.55 & 0 & Early oil \\
\hline & Sadi & 0.55 & 6.67 & Early oil & 0.63 & 0 & Early oil \\
\hline & Hartha & 0.55 & 6.57 & Early oil & 0.61 & 0 & Early oil \\
\hline & Shrinish & 0.55 & 6.14 & Early oil & 0.59 & 0 & Early oil \\
\hline & Aaliji & 0.55 & 5.85 & Early oil & 0.58 & 0 & Early oil \\
\hline & Jadali & 0.55 & 4.99 & Early oil & 0.56 & 0 & Early oil \\
\hline \multirow[t]{7}{*}{ Am-2 } & Yamama & 0.55 & 12.71 & Early oil & 0.73 & 0 & Main oil \\
\hline & Ratawi & 0.55 & 11.01 & Early oil & 0.7 & 0 & Main oil \\
\hline & Zubair & 0.55 & 9.71 & Early oil & 0.67 & 0 & Early oil \\
\hline & Shuaiba & 0.55 & 8.2 & Early oil & 0.64 & 0 & Early oil \\
\hline & Nahr Umr & 0.55 & 7.92 & Early oil & 0.63 & 0 & Early oil \\
\hline & Mauddud & 0.55 & 6.74 & Early oil & 0.6 & 0 & Early oil \\
\hline & Ahmadi & 0.55 & 5.89 & Early oil & 0.58 & 0 & Early oil \\
\hline \multirow[t]{14}{*}{ HF-5 } & Yamama & 0.55 & 15.83 & Early oil & 0.99 & 0 & Main oil \\
\hline & Ratawi & 0.55 & 12.39 & Early oil & 0.94 & 0 & Main oil \\
\hline & Zubair & 0.55 & 11.76 & Early oil & 0.89 & 0 & Main oil \\
\hline & Shuaiba & 0.55 & 11.06 & Early oil & 0.83 & 0 & Main oil \\
\hline & Nahr Umr & 0.55 & 10.61 & Early oil & 0.81 & 0 & Main oil \\
\hline & Mishrif (1/2) & 0.55 & 6 & Early oil & 0.62 & 0 & Early oil \\
\hline & Mishrif (2/2) & 0.55 & 5.1 & Early oil & 0.58 & 0 & Early oil \\
\hline & Khasib & 0.55 & 3.34 & Early oil & 0.57 & 0 & Early oil \\
\hline & Tanuma & 0.55 & 1.58 & Early oil & 0.55 & 0 & Early oil \\
\hline & Sadi & 0.55 & 6.67 & Early oil & 0.63 & 0 & Early oil \\
\hline & Hartha & 0.55 & 6.57 & Early oil & 0.61 & 0 & Early oil \\
\hline & Shrinish & 0.55 & 6.14 & Early oil & 0.59 & 0 & Early oil \\
\hline & Aaliji & 0.55 & 5.85 & Early oil & 0.58 & 0 & Early oil \\
\hline & Jadali & 0.55 & 4.99 & Early oil & 0.56 & 0 & Early oil \\
\hline \multirow[t]{9}{*}{$\mathrm{Am}-2$} & Yamama & 0.55 & 12.71 & Early oil & 0.73 & 0 & Main oil \\
\hline & Ratawi & 0.55 & 11.01 & Early oil & 0.7 & 0 & Main oil \\
\hline & Zubair & 0.55 & 9.71 & Early oil & 0.67 & 0 & Early oil \\
\hline & Shuaiba & 0.55 & 8.2 & Early oil & 0.64 & 0 & Early oil \\
\hline & Nahr Umr & 0.55 & 7.92 & Early oil & 0.63 & 0 & Early oil \\
\hline & Mauddud & 0.55 & 6.74 & Early oil & 0.6 & 0 & Early oil \\
\hline & Ahmadi & 0.55 & 5.89 & Early oil & 0.58 & 0 & Early oil \\
\hline & Rumaila & 0.55 & 5.83 & Early oil & 0.57 & 0 & Early oil \\
\hline & Mishrif (1/2) & 0.55 & 1.5 & Early oil & 0.55 & 0 & Early oil \\
\hline
\end{tabular}


According to the results of the figures (5 to 12), it is obvious that the organic richness of the Siba gas field is better than that for Zubair oilfield. In Nahr Umr oilfield, the organic richness in NR-12 is better than NR-9 well. On the other hand, comparing organic richness in Zubair, Siba and provides that Nahr Umr well have more mature then Zubair and Siba wells. In contrast, the more richness is observed in NR-12 well in Basrah area. In Majnoon oilfield, the order of organic richness of wells was as follows: $\mathrm{Mj}-11>\mathrm{Mj}-12>\mathrm{Mj}-8$. If we compared NR-12 with Mj-11, the first was more mature.

In Amara area, the Mj-12 well has a high value of organic richness than that for Kt-1 well. Although the richness of Kt-1 is better than NR-12, NR-12 reach to the late oil stage in Yamama Formation. If we compared HF-5 with Kt-1 we noticed that HF-5 has more richness. But, the comparison between HF-5 and NR-12 indicated that HF-5 was more richness for all formations except or Yamama Formation which has more richness in NR-12. For Amara oilfield, if we compare with HF-5 the last have better values of richness.

\section{B. Transformation ratio $\left(T_{R}\right)$}

It is defined as the converted mass fraction of the initial reactant (Chilingarian et al., 2005). Anomalously high values for the bitumen ratio $\left(T_{R}\right)$ in immature sediments can be used to show contamination by migrated oil or manmade products (Peters et al., 2005). The difference between the original hydrocarbon potential of a sample before maturation and the measured hydrocarbon potential divided by the original hydrocarbon potential (ranges from 0 to 1) (Peters et al., 2005). Figures (13 to 18) show the transformation ratio in the study area.

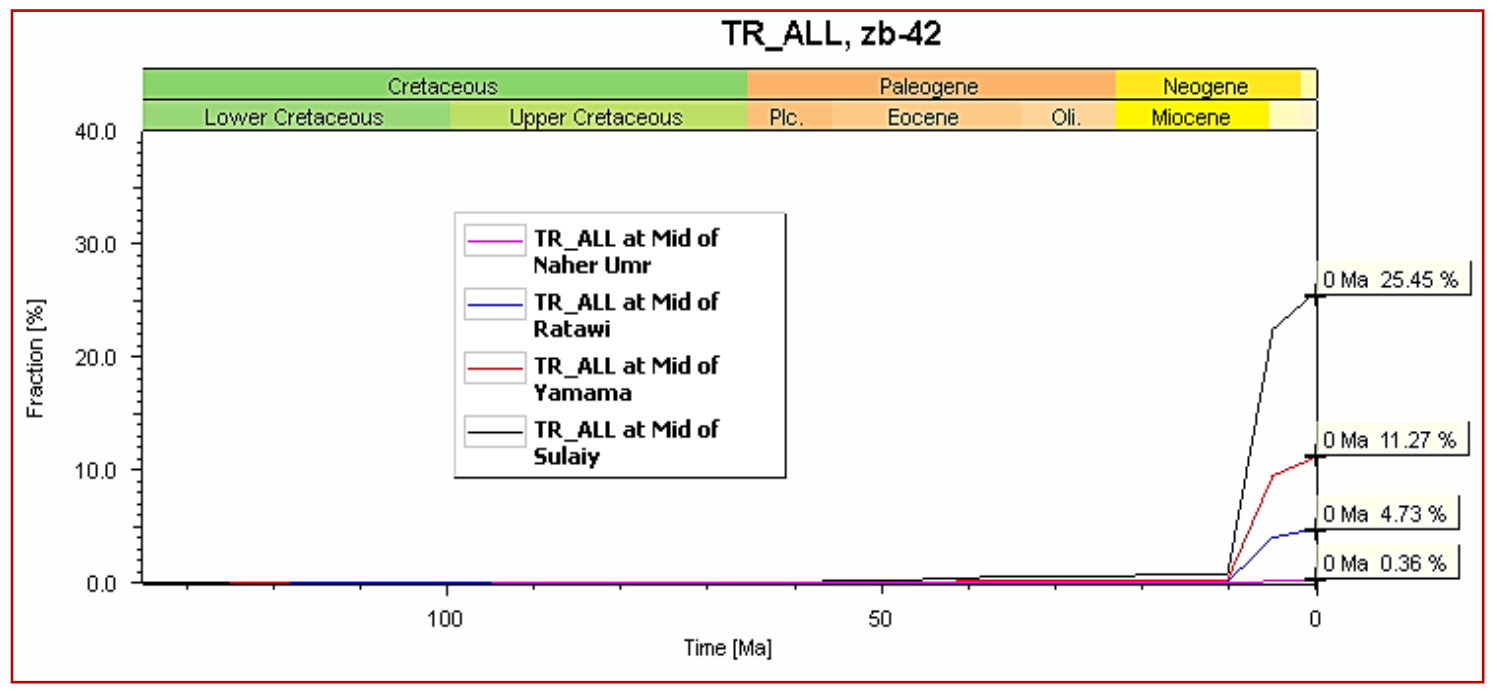

Fig. 13: Transformation ratio $\left(T_{R}\right)$ for well $Z b-42$ 


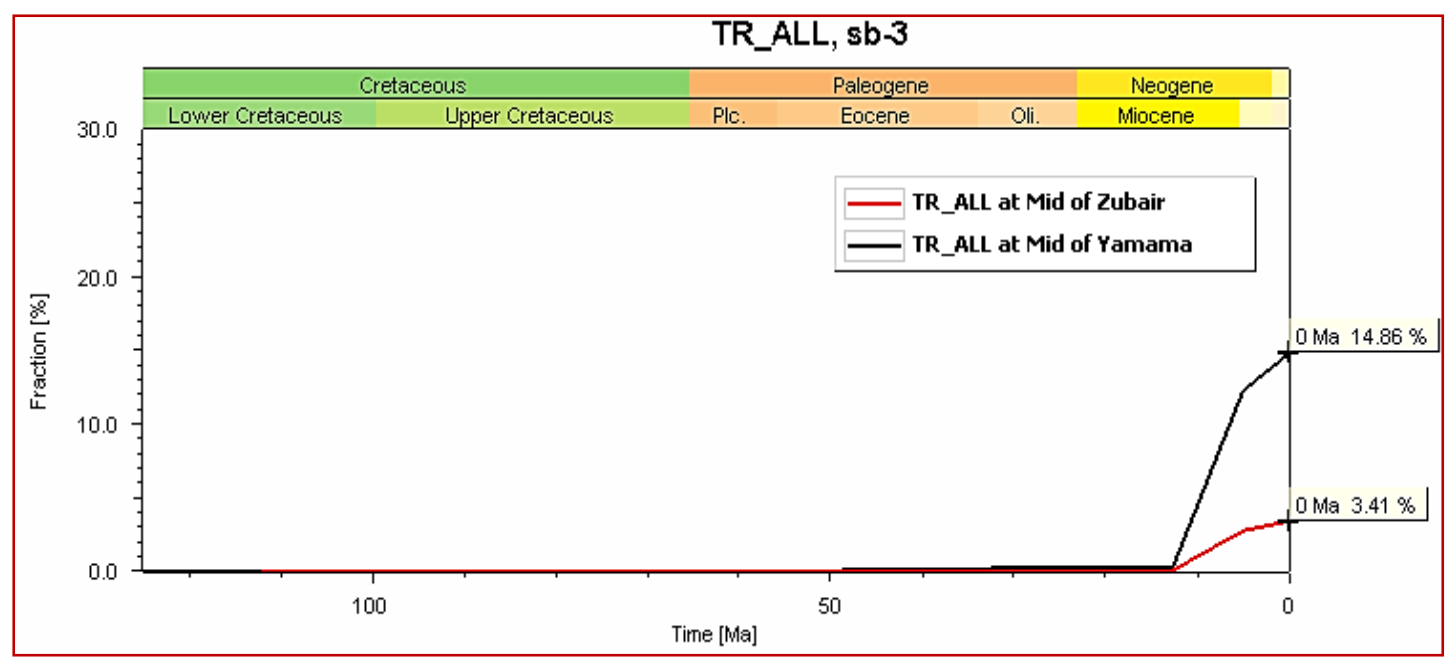

Fig. 14: Transformation ratio $\left(T_{R}\right)$ for well $\mathrm{Sb}-3$

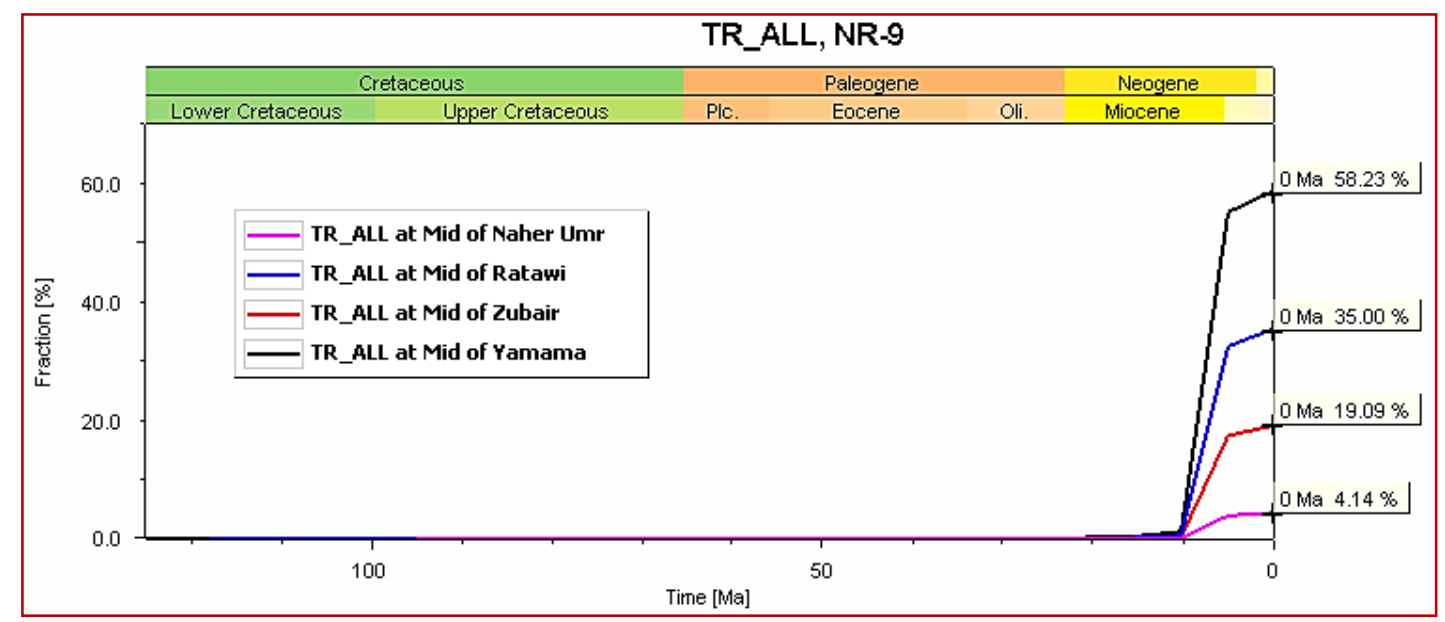

Fig. 15: Transformation ratio $\left(T_{R}\right)$ for well NR-9

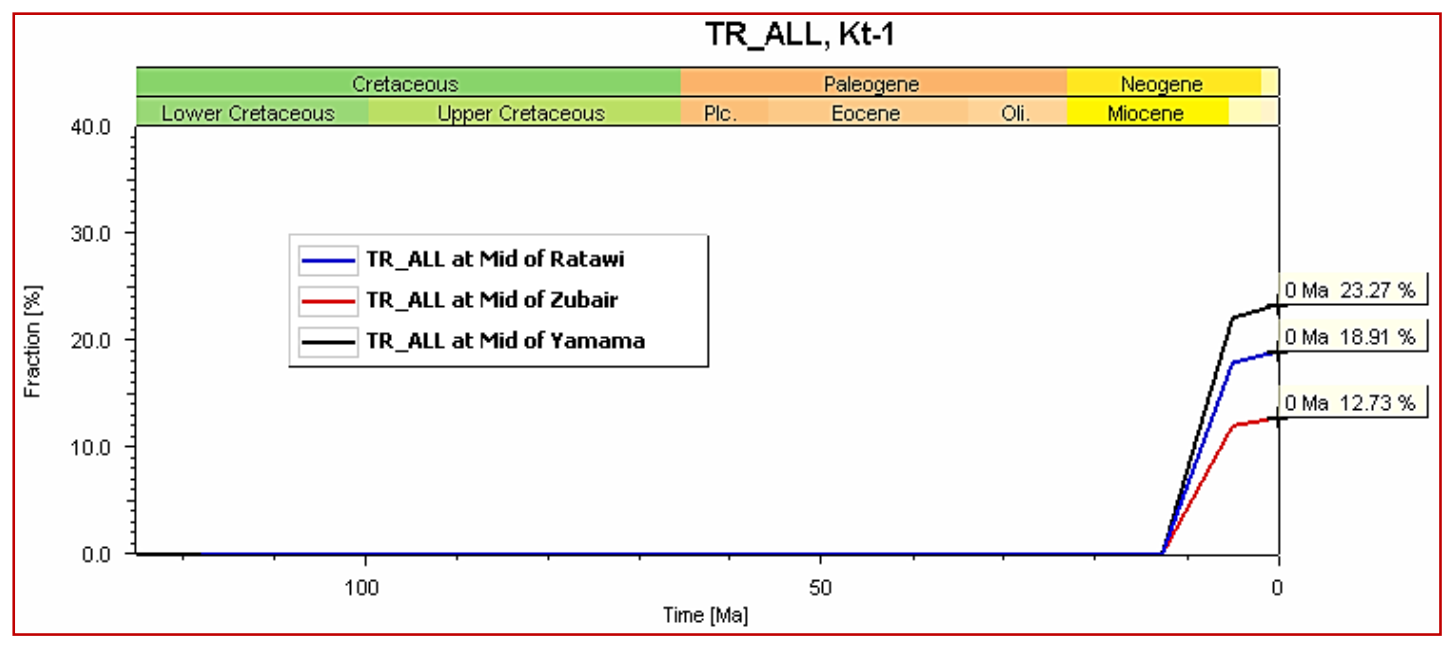

Fig. 16: Transformation ratio $\left(T_{R}\right)$ for well Kt-1 


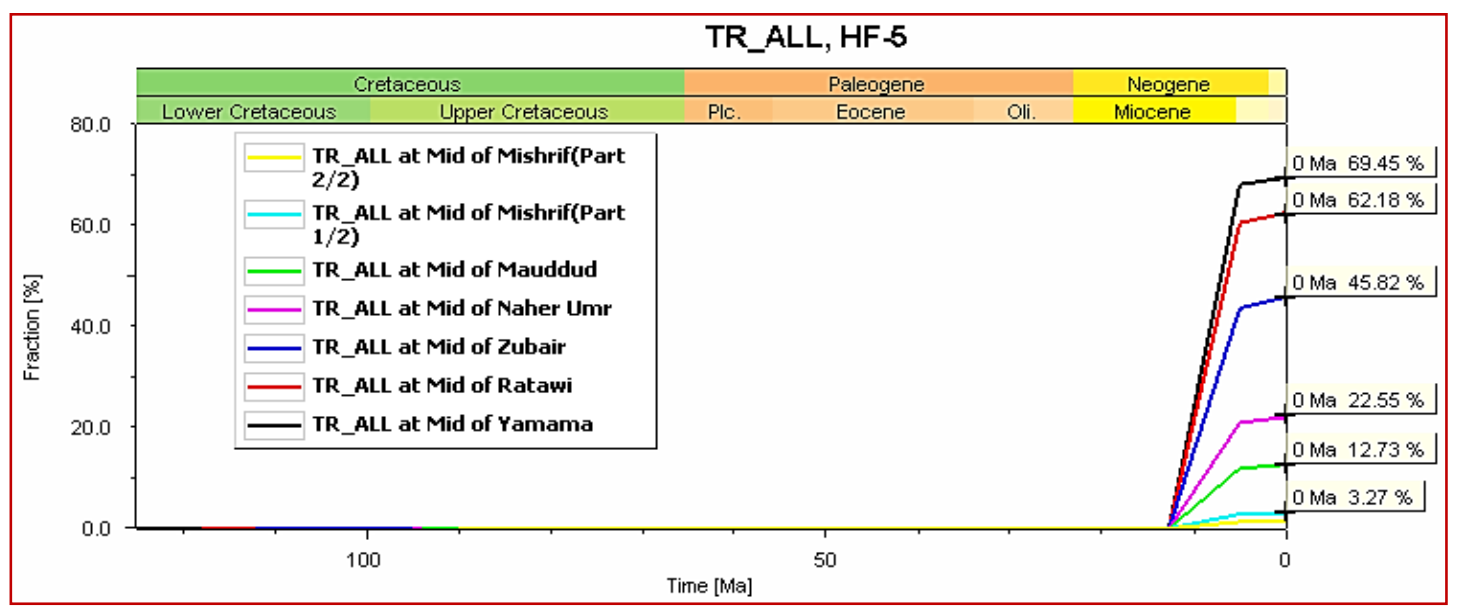

Fig. 17: Transformation ratio $\left(T_{R}\right)$ for well HF-5

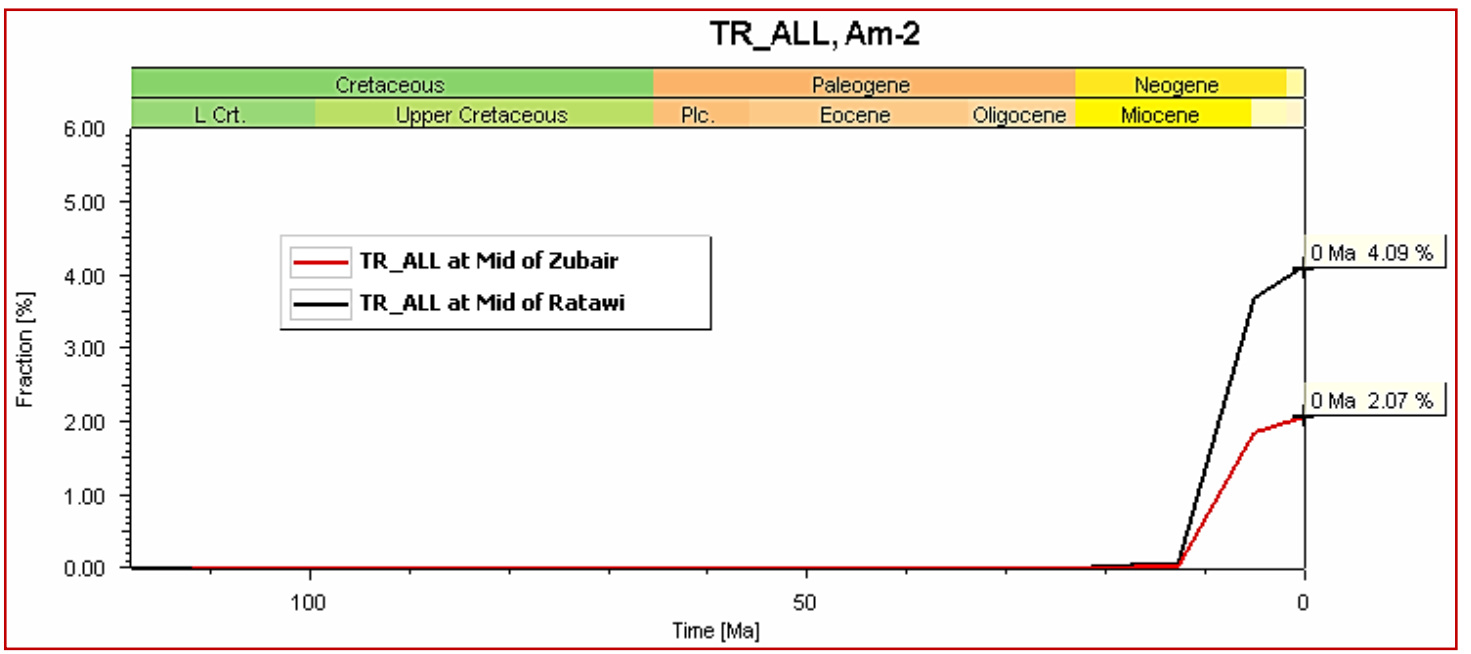

Fig. 18: Transformation ratio $\left(T_{R}\right)$ for well Am-2

Comparing the transformation ratio of $\mathrm{Zb}-42$ and $\mathrm{Sb}-3$ (Table. 2) demonstrated the Sb-3 was better than the former of Yamama Formation. We also noticed that this ratio was higher in NR-9 than that in Sb-3 for Yamama Formation and Zubair Formation. By comparing NR-9 and Kt-1, NR-9 has higher values of this ratio than Kt-1 for Yamama, Ratawi and Zubair Formations. For Kt-1 and Am-2, Kt-1 was better than Am-2 for Ratawi and Zubair formations, while the comparison between Kt-1 and HF-5 showed that HF-5 has more transformation ratio than Kt-1 for Yamama, Ratawi and Zubair Formations. When comparing this value between NR-9 and HF-5, HF-5 has the larger one for Yamama, Ratawi, Zubair, and Nahr Umr. HF-5 has the greatest values of transformation ratio $(69.45 \%)$ in Yamama Formation. 
Table 2: Transformation ratio $\left(T_{R}\right)$ results for the study area

\begin{tabular}{|c|c|c|c|c|c|}
\hline \multirow[b]{2}{*}{ Well No. } & \multirow[b]{2}{*}{ Formation } & \multicolumn{2}{|c|}{ Start } & \multicolumn{2}{|c|}{ End } \\
\hline & & $\mathbf{T}_{\mathrm{R}} \%$ & $\begin{array}{l}\text { Time } \\
\text { (Ma) }\end{array}$ & $\mathbf{T}_{\mathrm{R}} \%$ & $\begin{array}{l}\text { Time } \\
\text { (Ma) }\end{array}$ \\
\hline \multirow[t]{4}{*}{$\mathrm{Zb}-42$} & Sulaiy & 1.77 & 9.9 & 25.45 & 0 \\
\hline & Yamama & 0.65 & 9.79 & 11.27 & 0 \\
\hline & Ratawi & 0.18 & 16.32 & 4.73 & 0 \\
\hline & Nahr Umr & 0.02 & 10.42 & 0.36 & 0 \\
\hline \multirow[t]{2}{*}{$\mathrm{Sb}-3$} & Yamama & 0.95 & 12.5 & 14.86 & 0 \\
\hline & Zubair & 0.2 & 12.5 & 3.41 & 0 \\
\hline \multirow[t]{4}{*}{ NR-9 } & Yamama & 1.09 & 10.21 & 58.23 & 0 \\
\hline & Ratawi & 0.36 & 10.42 & 35 & 0 \\
\hline & Zubair & 0.55 & 10.08 & 19.09 & 0 \\
\hline & Nahr Umr & 0.04 & 10.29 & 4.14 & 0 \\
\hline \multirow[t]{3}{*}{ Kt-1 } & Yamama & 0.73 & 12.5 & 23.27 & 0 \\
\hline & Ratawi & 0.14 & 12.59 & 18.91 & 0 \\
\hline & Zubair & 0.14 & 12.51 & 12.73 & 0 \\
\hline \multirow[t]{7}{*}{ HF-5 } & Yamama & 0.36 & 12.5 & 69.45 & 0 \\
\hline & Ratawi & 0.36 & 12.59 & 62.18 & 0 \\
\hline & Zubair & 0.27 & 12.51 & 45.82 & 0 \\
\hline & Nahr Umr & 0.18 & 12.51 & 22.55 & 0 \\
\hline & Mauddud & 0.14 & 12.38 & 12.73 & 0 \\
\hline & Mishrif (1/2) & 0.02 & 12.6 & 3.27 & 0 \\
\hline & Mishrif (2/2) & 0.01 & 12.45 & 1.38 & 0 \\
\hline \multirow[t]{2}{*}{ Am-2 } & Ratawi & 0.35 & 9.83 & 4.09 & 0 \\
\hline & Zubair & 0.13 & 9.89 & 2.07 & 0 \\
\hline
\end{tabular}

\section{Generation Mass}

The generation of petroleum components from kerogen (primary cracking) and the secondary cracking of petroleum are usually described with sets of parallel reaction and decomposition kinetics (Hantschel and Kauerauf, 2009). The generation mass (Mega tons (Mtons)) of the study area is shown in Figures (19 to 24).

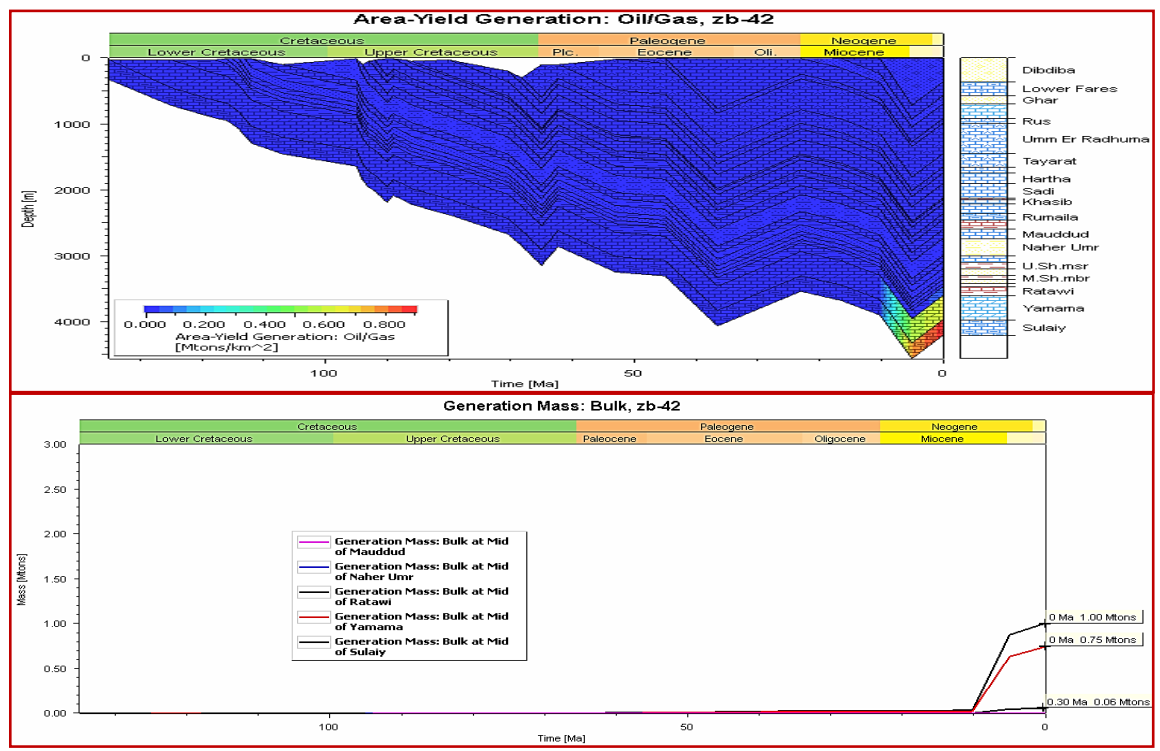

Fig. 19: Generation Mass for well $\mathrm{Zb}-42$ 


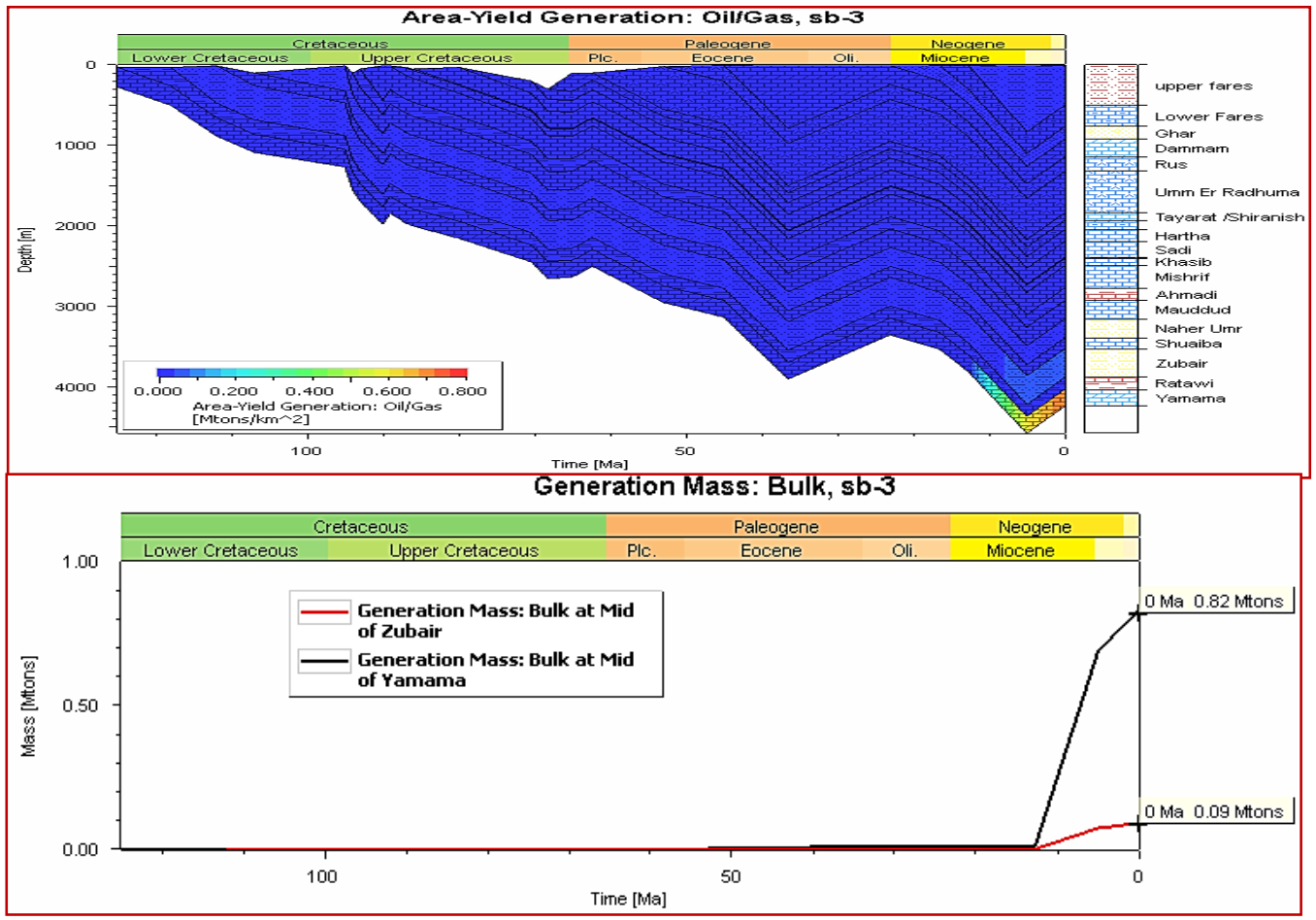

Fig. 20: Generation Mass for well Sb-3
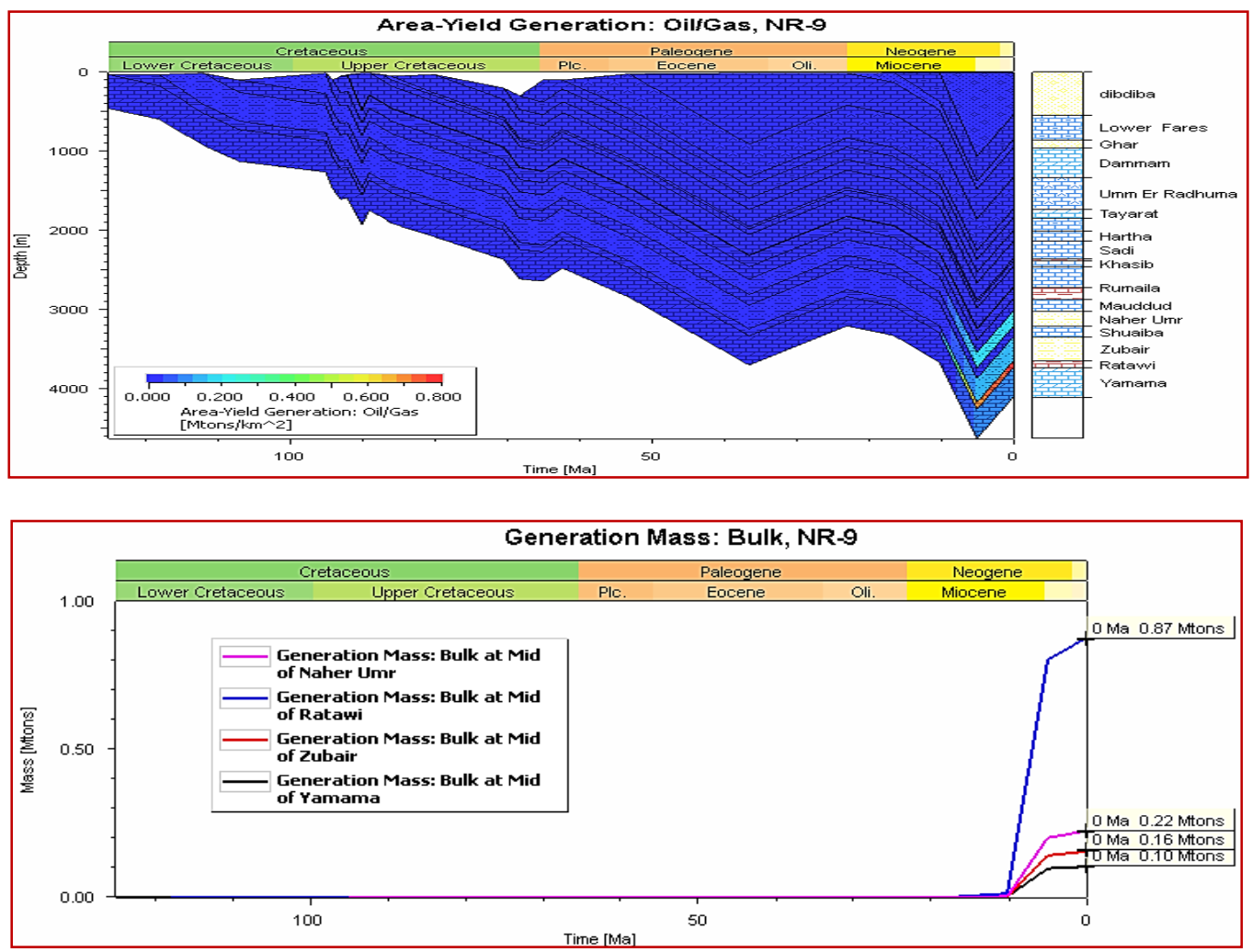

Fig. 21: Generation Mass for well NR-9 

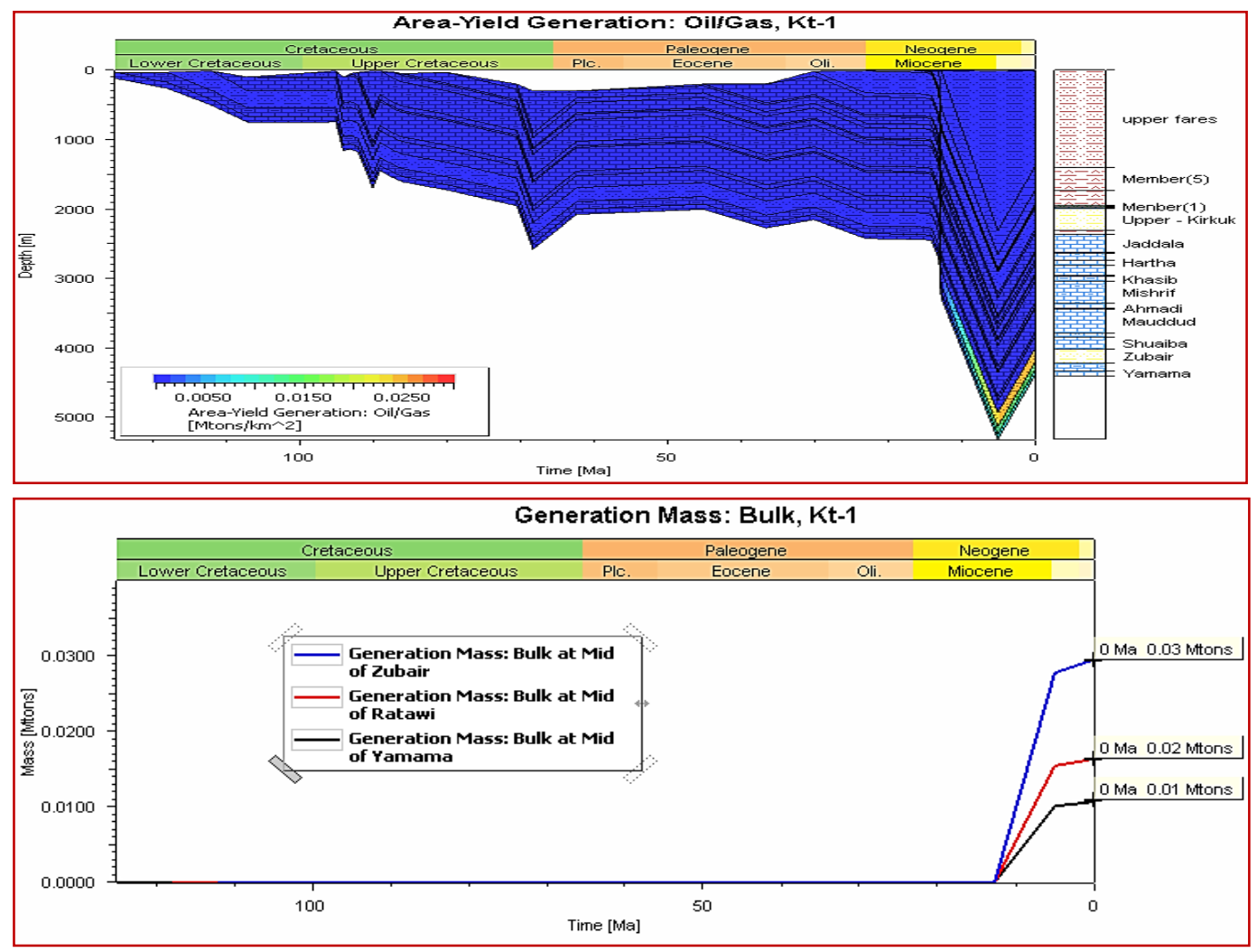

Fig. 22: Generation Mass for well Kt-1
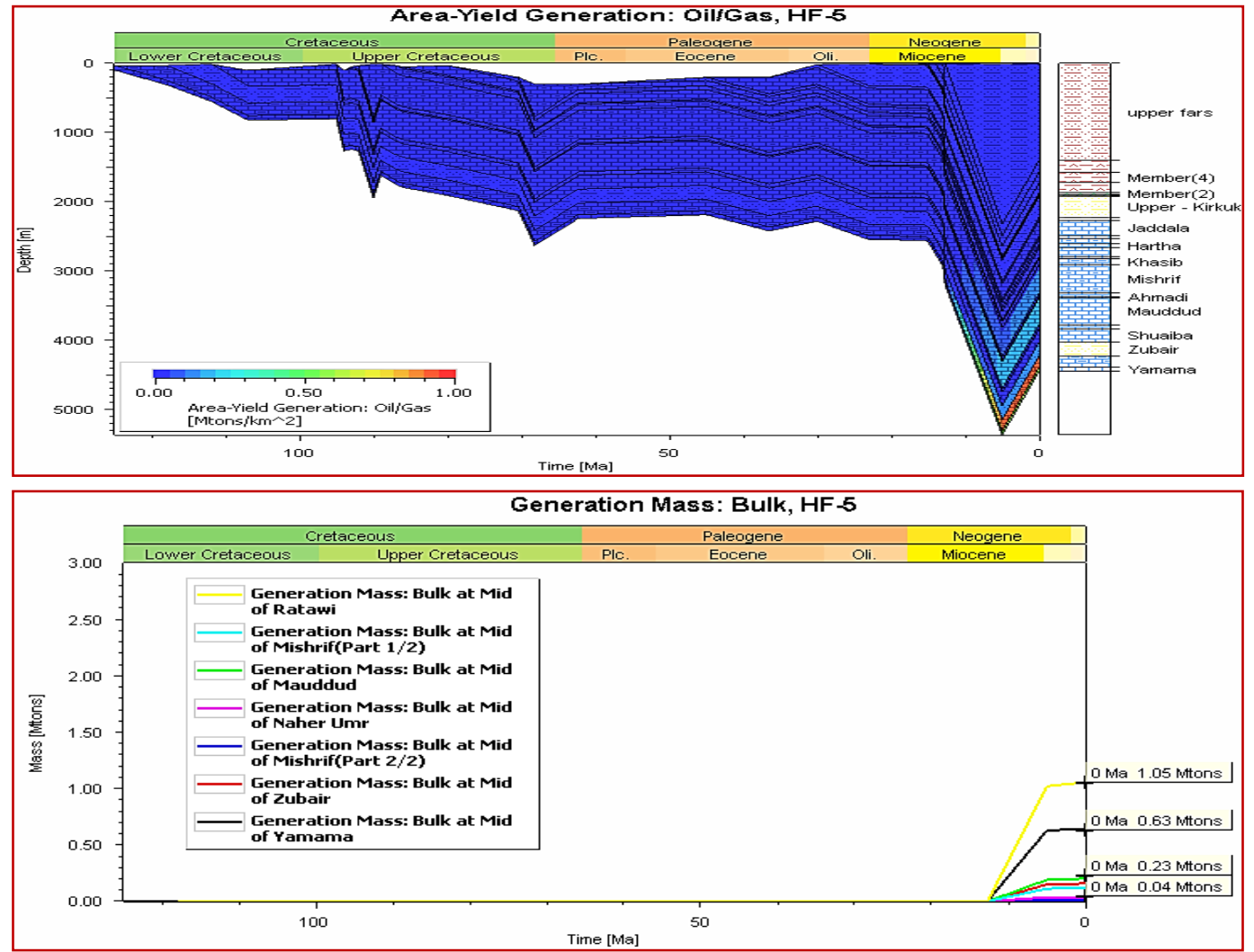

Fig. 23: Generation Mass well HF-5 

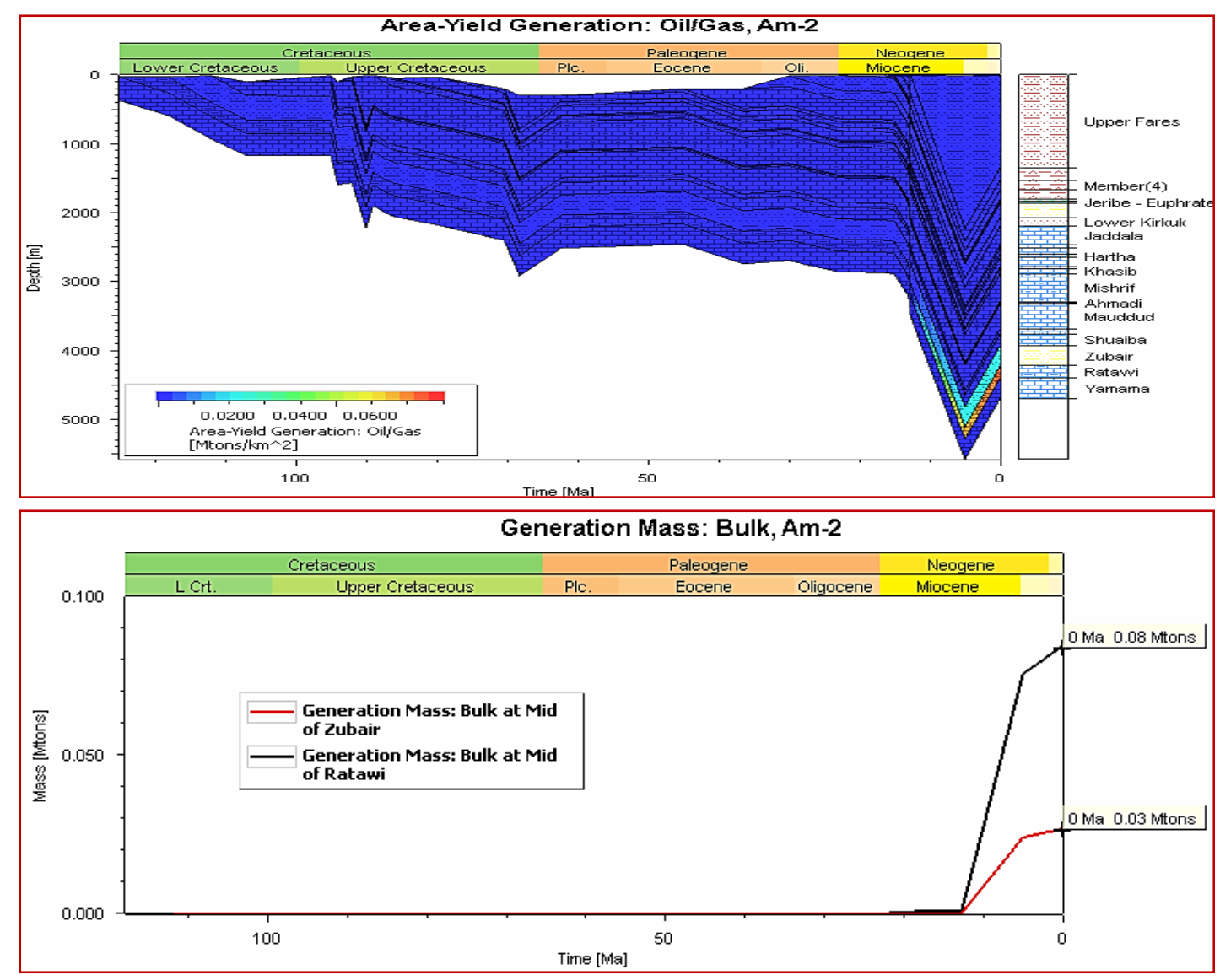

Fig. 24: Generation Mass for well Am-2

Comparing the generation mass of Zb-42 and Sb-3 wells (Table. 3) demonstrated the Sb-3 was better than for $\mathrm{Zb}-42$. We also noticed a higher value of generation mass in Sb-3 than that in NR-9 for Yamama Formation. The arrangement, of generation mass in Yamama Formation was follows: Sb-3 $>$ Zb-42 $>$ HF-5 $>$ NR-9 $>$ Kt-1. The arrangement, of generation mass in Ratawi Formation was as: HF-5 $>$ NR-9 $>$ Sb-3 $>$ Am-2 $>$ Zb-42 $>$ Kt-1. In Zubair Formation, NR-9 has higher values than Sb-3. The order of generation mass in Zubair Formation was NR-9 $>$ HF-5 $>$ Sb-3 $>$ Kt-1 = Am-2. The order of generation mass in Nahr Umr Formation was NR-9 $>$ HF-5 $>$ Zb-42. The order of generation mass in Mauddud Formation was HF-5 $>$ Zb-42. 
Table 3: Generation mass of the study area

\begin{tabular}{|c|c|c|c|c|c|}
\hline \multirow[b]{2}{*}{ Well No. } & \multirow[b]{2}{*}{ Formation } & \multicolumn{2}{|c|}{ Start } & \multicolumn{2}{|l|}{ End } \\
\hline & & $\begin{array}{l}\text { Genration mass } \\
\text { (Mtons) }\end{array}$ & Time (Ma) & $\begin{array}{l}\text { Genration mass } \\
\text { (Mtons) }\end{array}$ & $\begin{array}{l}\text { Time } \\
\text { (Ma) }\end{array}$ \\
\hline \multirow[t]{5}{*}{$\mathrm{Zb}-42$} & Sulaiy & 0.03 & 45.67 & 1.01 & 0 \\
\hline & Yamama & 0.02 & 41.67 & 0.74 & 0 \\
\hline & Ratawi & 0.01 & 9.64 & 0.06 & 0 \\
\hline & Nahr Umr & \multicolumn{4}{|c|}{ Very few } \\
\hline & Mauddud & \multicolumn{4}{|c|}{ Very few } \\
\hline \multirow[t]{2}{*}{ Sb-3 } & Yamama & 0.01 & 46.04 & 0.83 & 0 \\
\hline & Zubair & 0.01 & 12.51 & 0.09 & 0 \\
\hline \multirow{4}{*}{ NR-9 } & Yamama & 0.01 & 9.79 & 0.1 & 0 \\
\hline & Ratawi & 0.01 & 11.8 & 0.88 & 0 \\
\hline & Zubair & 0.01 & 10.08 & 0.66 & 0 \\
\hline & Nahr Umr & 0.01 & 10.13 & 0.23 & 0 \\
\hline \multirow[t]{3}{*}{ Kt-1 } & Yamama & Few & 12.29 & 0.01 & 0 \\
\hline & Ratawi & Few & 12.59 & 0.02 & 0 \\
\hline & Zubair & Few & 12.69 & 0.03 & 0 \\
\hline \multirow[t]{7}{*}{ HF-5 } & Yamama & 0.01 & 12.71 & 0.65 & 0 \\
\hline & Ratawi & 0.01 & 12.59 & 1.05 & 0 \\
\hline & Zubair & 0.01 & 12.32 & 0.16 & 0 \\
\hline & Nahr Umr & Few & 12.51 & 0.04 & 0 \\
\hline & Mauddud & 0.01 & 12.38 & 0.2 & 0 \\
\hline & Mishrif (1/2) & Few & 12.6 & 0.12 & 0 \\
\hline & Mishrif (2/2) & Few & 12.15 & 0.01 & 0 \\
\hline \multirow[t]{2}{*}{ Am-2 } & Ratawi & Few & 12.59 & 0.09 & 0 \\
\hline & Zubair & Few & 12.51 & 0.03 & 0 \\
\hline
\end{tabular}

\section{MIGRATION AND ACCUMULATION}

The concept of primary migration of oil (expulsion) as a result of the compaction was widely accepted for a long time (Chilingarian et al., 2005). The compaction and consolidation of carbonate oozes are accompanied by crystallization and often with the appearance of numerous micro-fractures, upon lithification, the mobile substance within the deposition in part becomes a component of the rocks and in part acquires the ability to move, upon dolomitization up to $13.1 \%$ porosity can from creating further avenues for migration (Chilingarian et al., 2005).

\section{A. Primary Migration}

In $\mathrm{Zb}-42$, the expulsion in Sulaiy Formation is higher than in all formations $\mathrm{Zb}-42$ that start at $10.35 \mathrm{Ma}$ by $0.055 \mathrm{Mtons} / \mathrm{km}^{2}$ and end at $0.22 \mathrm{Ma}$ by $1.118 \mathrm{Mtons} / \mathrm{km}^{2}$.while in Yamama Formation is range (0.011-0.404) Mtons/ $\mathrm{km}^{2}$ at (5-0.21) Ma respectively (Fig. 25). In Sb-3, the expulsion in Yamama Formation starts at $0.095 \mathrm{Mtons} / \mathrm{km}^{2}$ in $12.08 \mathrm{Ma}$ (Miocene) to 1.841 Mtons/ $\mathrm{km}^{2}$ in $0.42 \mathrm{Ma}$ that index the migration happened at Miocene to Pliocene (Fig. 26). In NR-9, the expulsion in Ratawi starts at $0.036 \mathrm{Mtons} / \mathrm{km}^{\wedge}$ at $10.03 \mathrm{Ma}$ to $0.891 \mathrm{Mtons} /$ $\mathrm{km}^{2}$ at $0.2 \mathrm{Ma}$ (Fig. 27). In HF-5, the highest value of expulsion is in Yamama Formation 
which is in range $0.013 \mathrm{Mtons} / \mathrm{km}^{2}$ at $12.71 \mathrm{Ma}$ to $0.554 \mathrm{Mtons} / \mathrm{km}^{2}$ at $0.21 \mathrm{Ma}$. In Ratawi $0.002 \mathrm{Mtons} / \mathrm{km}^{2}$ at $12.59 \mathrm{Ma}$ to $0.323 \mathrm{Mtons} / \mathrm{km}^{2}$ at $0 \mathrm{Ma}$ (Fig. 28).

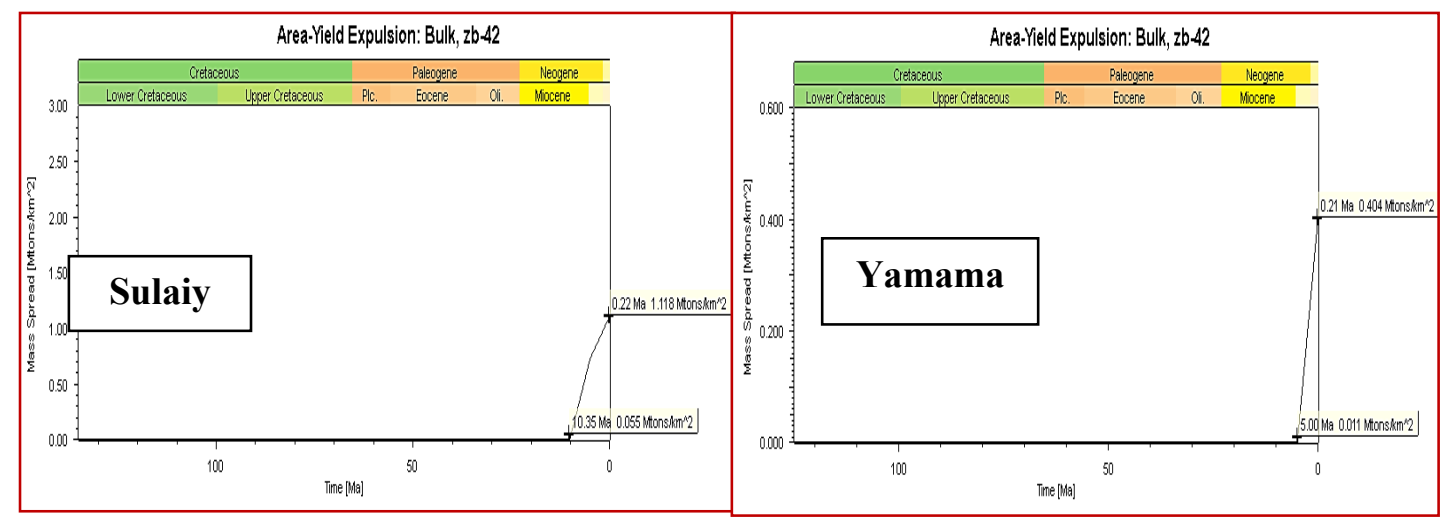

Fig. 25: Expulsion for Sulaiy and Yamama formations in well $\mathrm{Zb}-42$

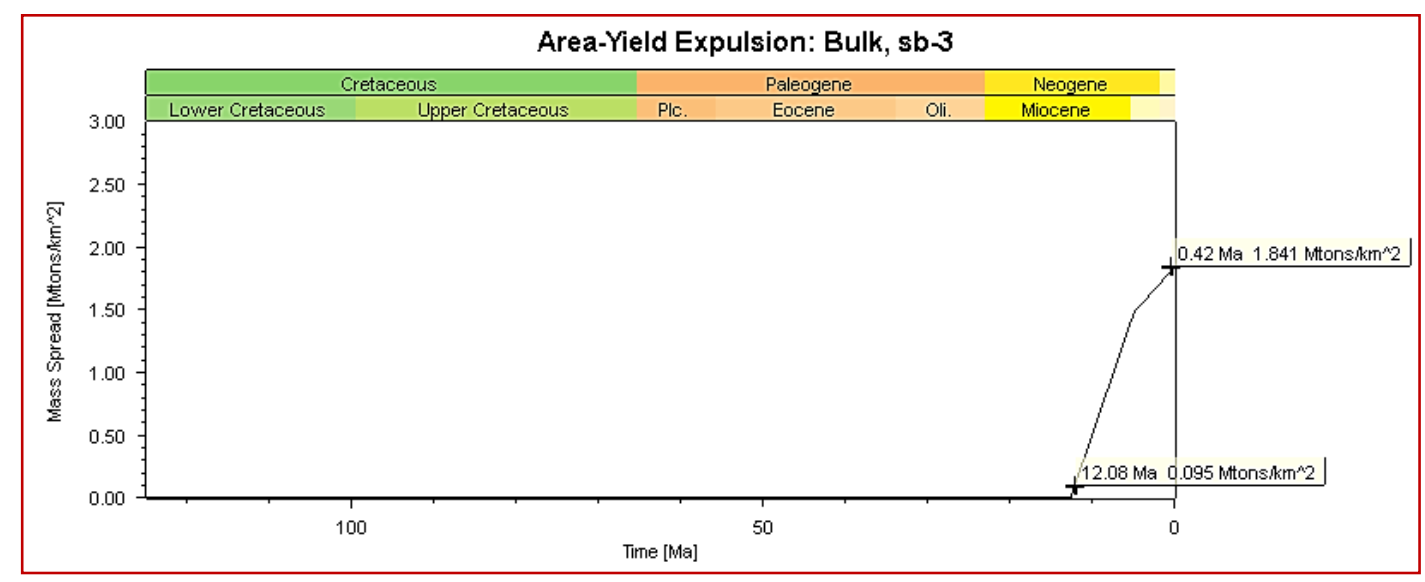

Fig. 26 Expulsion for Yamama Formation in well Sb-3

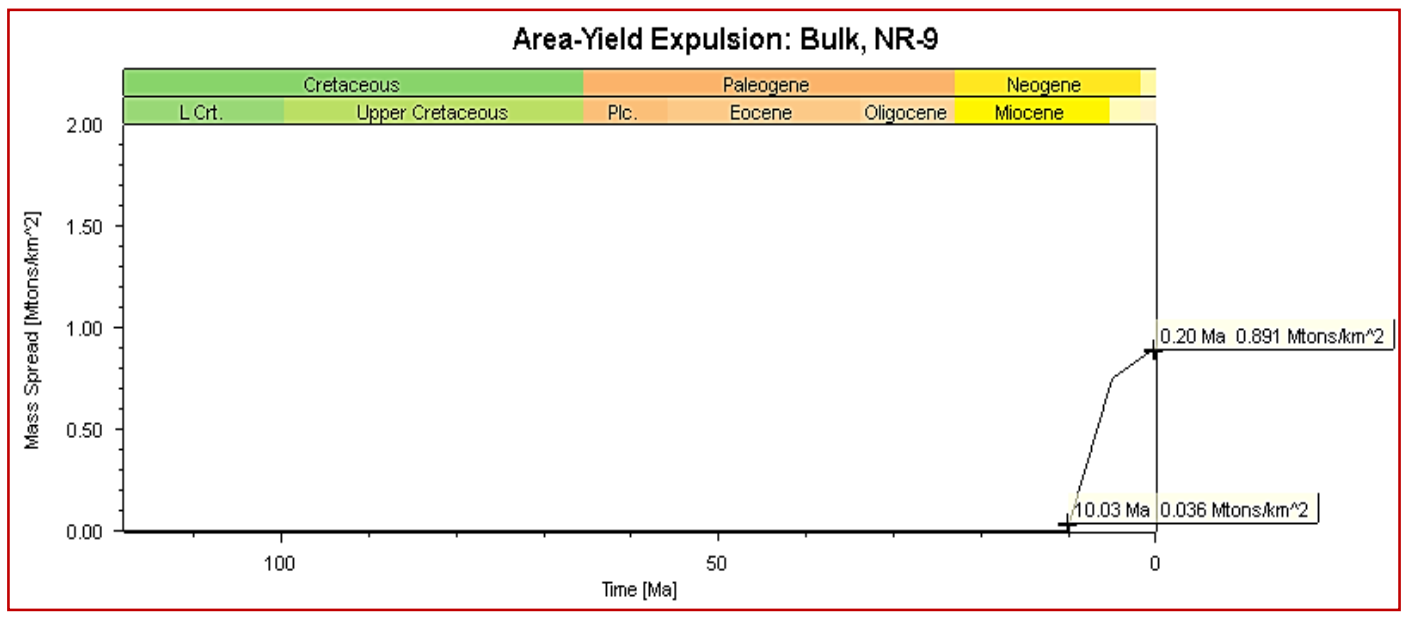

Fig. 27: Expulsion for Ratawi Formation in well NR-9 


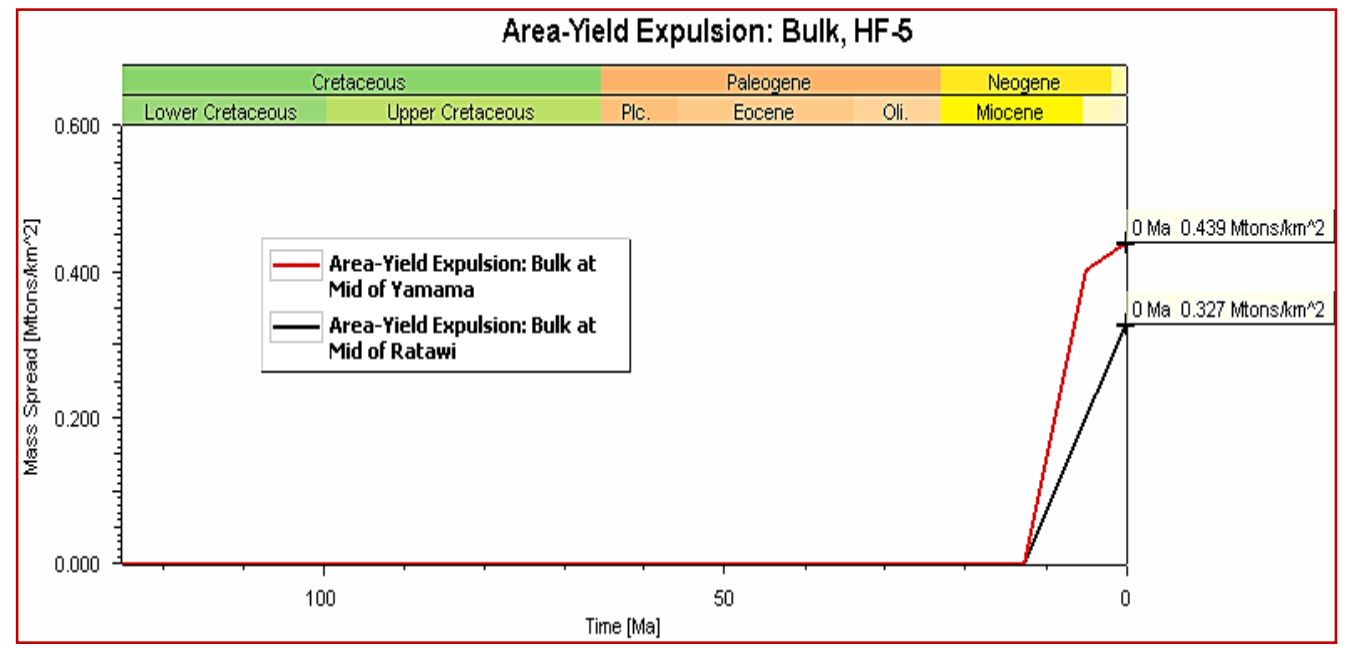

Fig. 28: Expulsion for Yamama and Ratawi formations in well HF-5 THERMAL HISTORY

The basin thermal history of a basin is an essential controlling factor on the generation and distribution of multiple energy sources acting in the basin (Welte and Yükler, 1981). For most of the studied wells, the Paleocene to Miocene are the times when the maximum temperature prevailed associated with deep burial. In the study area, deep burial was followed by erosion in Pliocene and Miocene (Fig. 29).

\section{THERMAL CONDUCTIVITY}

The conductive heat transport is mainly used to know the distribution of temperature with depth in the continents (Allen and Allen, 2005). Thermal conductivities of sedimentary vary as a function of depth due to their porosity loss with burial. The lithology is a factor affects thermal conductivity. The high thermal conductivity minerals such as quartz, halite, and anhydrite increase thermal conductivity of a rock.

In Zb-42 and Sb-3, the thermal conductivities of Rus and Umm Er-Radhuma formations are high despite their low geothermal gradient. In contrast, the thermal conductivities of Tanuma and Zubair formations are low despite having a high geothermal gradient. In NR-9, NR-7 and NR-12 thermal conductivity is high in Umm Er-Radhuma Formation and low in fTanuma and Zubair Formations. Mj-12 thermal conductivity is high in lower Fars (Fatha) and Umm Er-Radhuma Formations and low in Ghar, Khasib and Ahmadi formations. In Kt-1, HF-5 and Am-2 thermal conductivities are high in Jeribe and Euphrates and approximately same in all other formations. The porosity and the fluid contained within the pores play a major role the difference of thermal conductivities for formations with the same rock composition. If formation contain saline formation water within the pore net, the thermal 
conductivity decrease as the porosity increase since the thermal conductivity of formation water is much less than for mineral (Fig. 30).

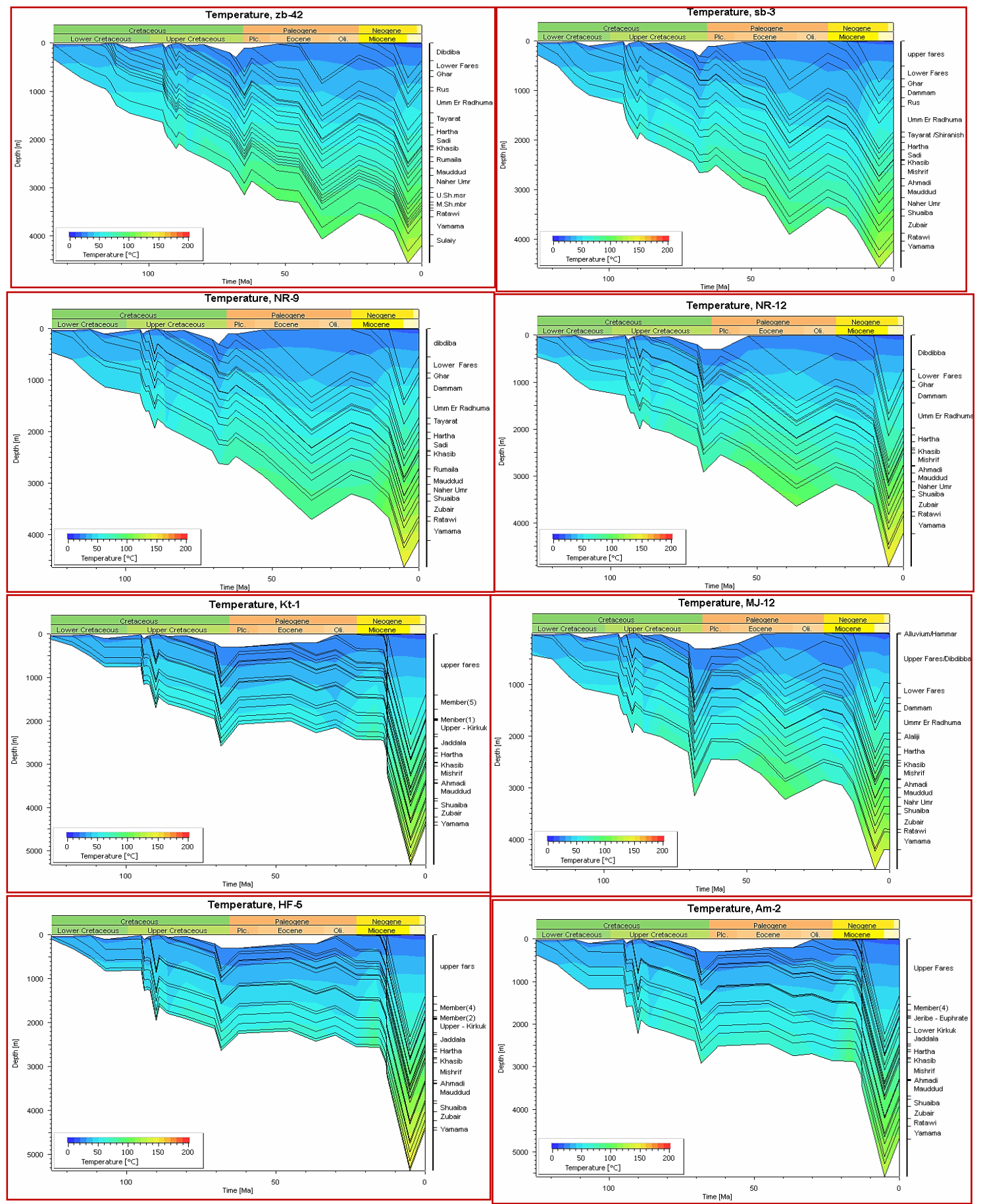

Fig. 29: Thermal history of the study area

The difference in thermal conductivities of formations having the same lithology could be attributed to porosity variations and contained fluid within pores. When pores fill with formation water, as porosity increases thermal conductivity decrease because thermal conductivity of formation water is much less than for mineral (Fig. 30). The porosity of 
typical hydrocarbon productive sandstones ranges between (3-38\%) in the gas reservoir and (10 38\%) in oil reservoir (Bowen, 2005). Porosity in carbonate rocks can be much more variable in magnitude than it is in sandstone and chalks; it is very high, in few cases exceeding $50 \%$

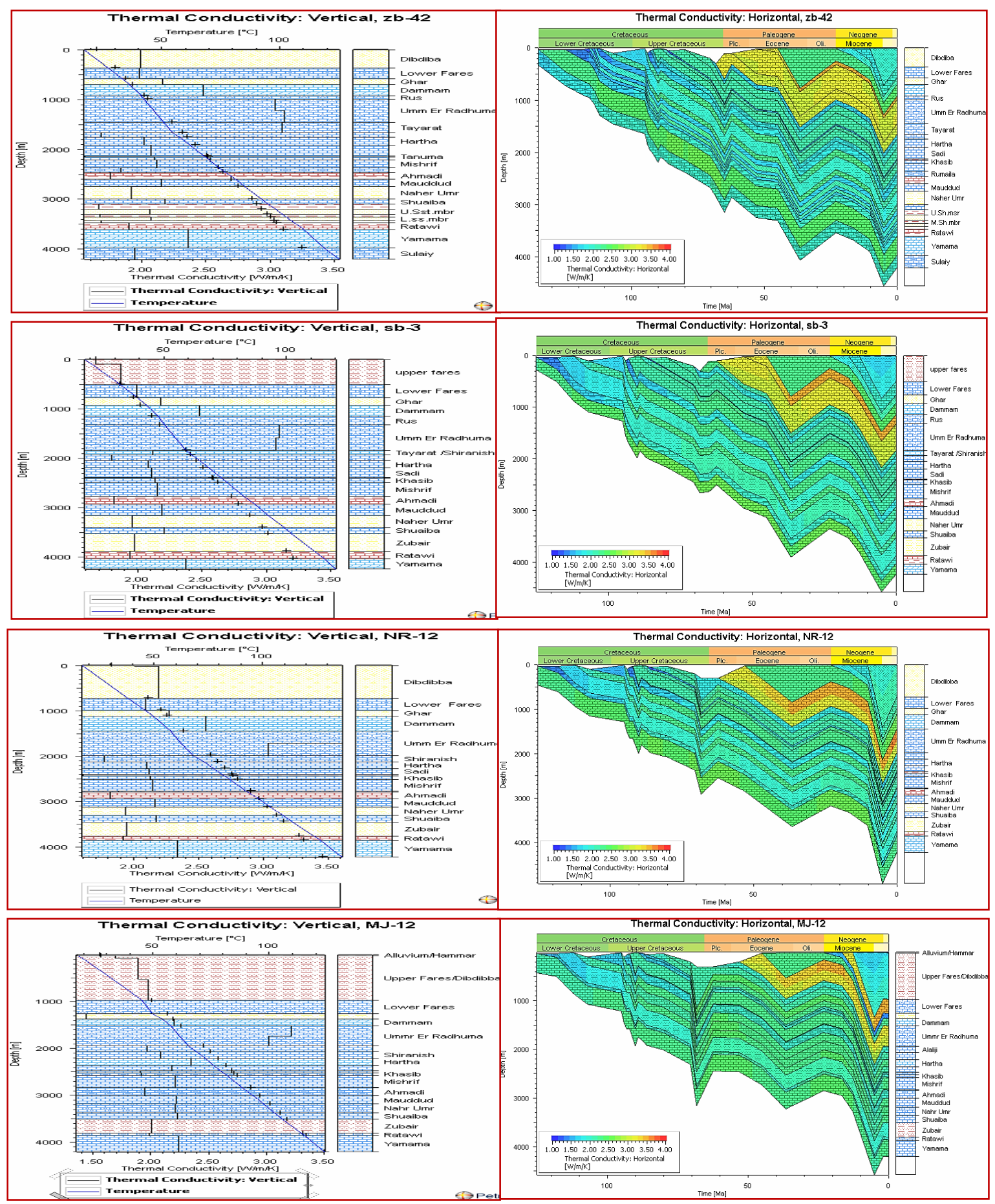

Fig. 30: Thermal conductivity of the study area 

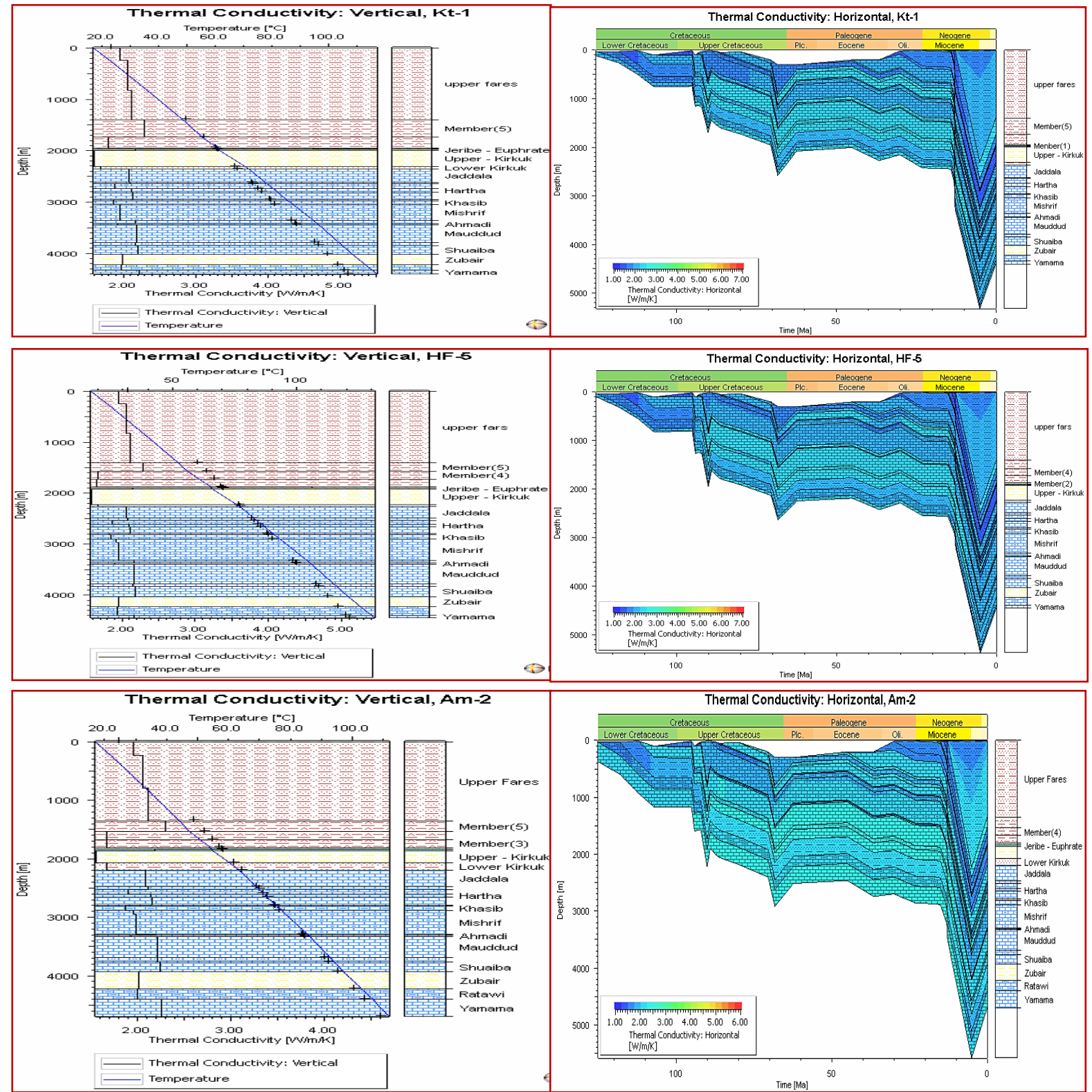

Fig. 30: Continued...

\section{EVENTS CHART FOR THE STUDIED WELLS}

Events chart (Fig. 31) summarizes those times when deposition of essential elements and the important processes that took place in the studied wells. The deposition of essential elements took place in Upper Jurassic-Upper Cretaceous. The time of deposition for the sources, reservoirs and seal rocks is only shown because the depositional system of the basin being studied varies laterally and vertically. The overburden rock required to thermally mature the source rock, includes rocks of Tertiary and overlying rock units. Since the hydrocarbon traps are strongly stratigraphic and structure, traps formation occurred during Lower Cretaceous 
and Late Cenozoic. Petroleum generation for much of the basin area occurred (12-45) Ma, with peak generation (critical moment) occurring about 13Ma.
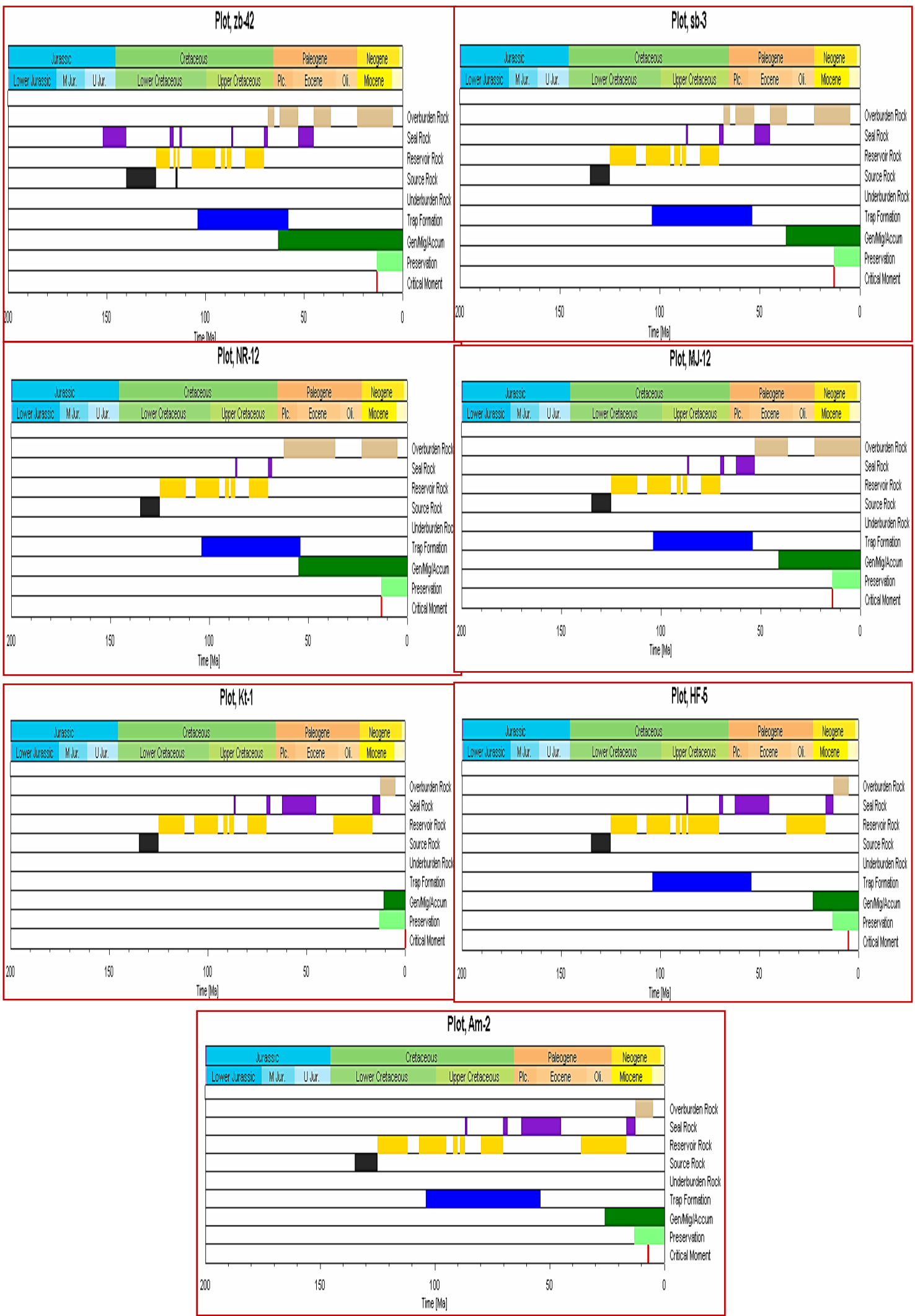

Fig. 31: Event charts for the study area 


\section{CONCLUSIONS}

1. The organic maturity initiated at Upper Cretaceous and Early Tertiary.

2. In both Basrah and Amara oilfields, the rocks mature as the result of increasing the sedimentary burial depth in Miocene (Alpine Orogeny effects)

3. The main oil stage begins in Miocene in Sulaiy and Yamama formations. The exception if the Yamama Formation in NR-12 that entered late oil stage at this age. The formations in Nahr Umr oilfield in Basrah are characterized by high organic maturation due to activity of faulting processes and salt but In general, the organic maturation in the Amara oilfields is greater than Basrah oilfields.

4. Sulaiy and Yamama formations can be considered as a source rocks in the studied oilfields.

5. The maximum transformation ratio $(69.45 \%)$ was recorded in Yamama Formation in Hf-5 well.

6. Migration of oil starts in Miocene in west and west-south trending.

7. The thermal conductivity of Rus and Umm Er-Radhuma formations in Basrah oilfields is high although they have low thermal gradient, while Zubair, Ahmadi, Khasib, Tanuma and Ghar formations is low although they have high thermal gradient because of the nature of mineral constituents of these formations. In Amara oilfield, both of Jeribe and Euphrates formations have high thermal conductivity; the other formations have low thermal conductivities.

8. Heat flow is in range $\left(27-70 \mathrm{~mW} / \mathrm{m}^{2}\right)$ which affects the thermal maturity in the studied wells.

9. The essential geological elements required for petroleum accumulation in the Mesopotamian basin include Upper Jurassic-Late Cretaceous source rocks (Sulaiy and Yamama formations), while the Cretaceous and Tertiary rocks were including reservoirs and seal rocks.

\section{REFRENCES}

Allen, P.A., and Allen, J. R., 2005. Basin analysis: principles and applications. Blackwell publishing, second edition, $549 \mathrm{pp}$.

Handhal, A. M., and Mahdi, M.M., 2016. Basin modeling analysis and organic maturation for selected wells from different oil fields, Southern Iraq. Modeling Earth Systems and Environment, Springer International Publishing Switzerland, 2(4): 1-14.

Bowen, D.G., 2005. Formation evaluation and petrophysics. Core laboratories, Jakarta, Indonesia, $237 \mathrm{pp}$.

Buday, T., and Jassim, S. Z., 1987. The Regional Geology of Iraq. Tectonism, Magmatism and Metamorphism. Publication of GEOSURV, Baghdad, $352 \mathrm{pp}$. 
Chilingarian, G.V, Buryakovsky, L., Eremenko, N.A., and Gorfunkel, M.V., 2005. Geology and Geochemistry of Oil and Gas. Developments in petroleum science, Elsevier Science, $390 \mathrm{pp}$.

Hantschel, T. and Kauerauf A.I., 2009. Fundamentals of Basin and Petroleum Systems Modeling. Springer-Verlag, Berlin, 476 pp.

Jassim, S.Z. and Buday, T., 2006c. Late Turonian-Danian Megasequence AP9. In; Jassim, S.Z. and Goff J.C. (Eds.), Geology of Iraq. Dolin, Prague and Moravian Museum, Brno, Czech Republic, pp.141- 151.

Jassim, S.Z., and Goff, J.C., 2006. Geology of Iraq. Published by Dolin, Prague and Moravian Museum, Brno, $341 \mathrm{pp}$.

McCulloh, T.H., and Naeser, N.D., 1989. Thermal history of sedimentary basins; introduction and overview. Springer-Verlag, 1-11.

Sadooni, F. and Aqrawi, A.A.M., 2000. Cretaceous sequence stratigraphy and petroleum potential of the Mesopotamian Basin, Iraq. In: Alsharhan, A. and Scott, B., (Eds.), Middle East Models of Jurassic-Cretaceous carbonate systems. SEPM Special Publication 69, 315-334.

Selley, R. C., 1998. Elements of Petroleum Geology. New York, Oxford: W. H. Freeman \& Company, $449 \mathrm{pp}$.

Sweeney, J.J. and Burnham, A.K., 1990. Evaluation of a simple model of vitrinite reflectance based on chemical kinetics. AAPG Bulletin, 74(10): 1559-1570.

Peters, K.E. Walters, C.C. and Moldowan, J.M., 2005. The Biomarker Guide. Cambridge University Press, U.K.

Welte, D.H. and Yükler, M.A., 1981. Petroleum origin and accumulation in basin evolution. A Quantitative Model. AAPG Bulletin, 65: 1387-1396. 